\title{
Takeover Likelihood Models for UK Quoted Companies
}

\author{
Robin Nuttall* \\ Nuffield College, \\ Oxford, \\ OX1 1NF, UK.
}

3 January 1999

\begin{abstract}
This paper estimates takeover likelihood models for UK quoted companies. For a sample of 643 UK nonfinancial quoted companies over the period 1989-96, we find that the probability of being a takeover target is increasing in leverage and incidence of takeover speculation and decreasing in pre-bid performance, size and age since listing. Friendly and hostile targets differ in terms of age, size and capital structure, but not pre-bid performance. Lapsed and successful takeover targets differ in terms of size and age. Overall, the evidence here is consistent with a disciplinary view of hostile takeovers, while for friendly takeovers it is consistent with financial distress, financial synergy, going-public-to-sell-out and managerialist motivations.
\end{abstract}

JEL classification: G34.

Keywords: Determinants of takeover; hostile and friendly takeover.

11600 words.

*This paper is based on Essay 3 of my doctoral thesis at Oxford University. I thank Steve Bond for his extensive advice and encouragement. I am also grateful to Scott Evans, Colin Mayer, Daphne Nicolitsas and Frank Windmeijer, plus seminar participants at Oxford and the London Business School. Any errors are mine. 


\section{Introduction}

What makes a company likely to become the target of a takeover bid? Will the bid be friendly or hostile? Will the bid succeed or fail? This paper addresses these questions by estimating takeover likelihood models for a panel of 643 quoted companies over the period 1989-96.

The question of what makes a company likely to become the target of a takeover bid is of interest for at least two reasons. First, a knowledge of the characteristics of takeover targets is necessary if we are to assess different theories of why takeovers occur in the first place and, relatedly, to assess the efficiency of the stock market in selecting those firms for which ownership changes. Secondly, the predicted probabilities from a takeover-likelihood model can be used as a measure of the intensity of the threat of takeover-a possibility explored more thoroughly in a companion paper (Nuttall, 1999a).

There have been many previous studies that have used takeover likelihood models (see Section 2), but this one is novel in that it combines analysis of the following issues. First, we make use of a new information source, namely data on takeover speculation collected from the Financial Times. Second, we use a multinomial exit framework, which distinguishes between two different kinds of takeover-hostile and friendly. Third, the distinction between failed and successful takeover attempts is considered.

The paper has six main findings, which are summarized at greater length in the Conclusion. First, the corporate control events within the following three groupings are statistically distinguishable with our data: takeovers, bankruptcy and survival; friendly and hostile takeover bids; and failed and successful takeover bids. Second, the probability of bankruptcy is greater for companies with poor profitability, companies that are young on the stock market, companies that are highly leveraged, and companies that are the subject of takeover rumours in the financial press. Tobin's Q has a negative effect on the probability of bankruptcy unconditionally, but conditional upon profitability has only a weak effect. This evidence is suggestive of the view that financial distress 
is a stronger predictor of bankruptcy than economic distress. Third, the probability of takeover is increasing in the incidence of takeover rumours and leverage. The probability of takeover is decreasing in pre-bid performance (whether measured by Tobin's Q or profitability), in age since listing and in company size. Fourth, there is no evidence of performance differences between hostile and friendly targets, though the age, size, leverage and rumour effects are much more pronounced for friendly acquireds than for hostile acquireds. Fifth, with regard to the distinction between successful versus failed takeover, successful targets are younger, smaller and perform worse than failed targets. Finally, takeover speculation in the financial press provides useful information over and above company accounts regarding corporate control events. In particular, we find that the probability of takeover is strongly increasing in the incidence of takeover speculation (especially targets of friendly and successful bids), and this is particularly the case for smaller firms. The probability of bankruptcy is also increasing in takeover speculation.

The implications of our results for theories of takeover are discussed at greater length below. In brief, however, for friendly takeovers, the evidence is consistent with three motives: financial distress (takeover as a less costly means of reallocating control over assets than bankruptcy); financial synergies (takeover as a means of reducing the impact of financing constraints); and initial public offerings as a means through which owners achieve more favourable terms for the sale of their companies (Zingales, 1995). For hostile takeovers the findings are consistent with a disciplinary motive, though this motive would be more strongly supported if hostile targets experienced poorer prebid performance than friendly targets. Our findings on hostile and friendly takeovers should be treated with some caution, because of the possibility that our scheme for classifying hostile/friendly bids is imperfect. Finally, there is weak evidence for the view that financial pressure and hostile takeover act as substitute mechanisms of corporate control.

The remainder of the paper is structured as follows. Section 2 outlines the existing literature on takeover likelihood models. Section 3 draws out the empirical predictions 
of existing theories of takeover. The data are described in Section 4, and Section 5 presents univariate descriptive statistics. Section 6 presents the multivariate analysis, and Section 7 concludes.

\section{Existing Literature}

There already exists an extensive literature on takeover likelihood models using US data, ${ }^{1}$ so we focus attention here on the UK studies, namely Powell (1997) and DickersonGibson-Tsakalotos (1998).

Powell (1997) uses a choice-based sample of 943 companies, of which 411 are acquired (97 hostile and 314 friendly) during the sample period of 1984-1991. ${ }^{2}$ In a binary logit model he finds that likelihood of being a (friendly or hostile) target is decreasing in size (the logarithm of total assets), decreasing in liquidity (cash and marketable securities/total assets), increasing in cash flow (Operating cash flow/total assets), increasing in the share of fixed assets in total assets relative to an industry average, and decreasing in industry sales growth relative to average growth.

Using a multinomial logit model, Powell (1997) finds that the likelihood of being a hostile target is increasing in size, decreasing in liquidity, increasing in the ratio of the market valuation to the book value of $\operatorname{assets}^{3}$ and decreasing in the 3-year average pre-bid ratio of operating profit to capital employed. The likelihood of being a friendly target is decreasing in size and increasing in leverage (measured as debt as a share of total share capital and reserves). He also finds that industry variables are important in many cases. He finds that the likelihood-ratio index is higher for the

\footnotetext{
${ }^{1}$ The standard logit takeover likelihood model was introduced by Palepu (1986). Morck, Shleifer and Vishny (1988) ran separate probit models for agreed and hostile takeovers. Morck, Shleifer and Vishny (1989) used a multinomial logit model to examine performance and management characteristics of firms experiencing one of three types of control change: internally precipitated management turnover, hostile takeover, and friendly takeover. Comment and Schwert (1997) assess whether hostile targets can be distinguished from friendly targets in terms of pre-bid characteristics. Comment and Schwert (1995) add to a takeover likelihood model measures of takeover defence mechanisms, such as poison pills. Shivdasani (1993) examines the impact of managerial and outside ownership on the probability of hostile and agreed takeover. Ambrose and Megginson (1992) assess the effect of institutional shareholdings on takeover likelihood. Mikkelson and Partch (1989) add in measures of affiliate-firm cross-holdings and target managers' holdings. See Nuttall (1999b) for a detailed survey of this evidence.

${ }^{2}$ From reading Powell (1997) it is not clear whether or not his sample includes any bankruptcies.

${ }^{3}$ Powell does not attempt to explain this positive market-to-book effect.
} 
multinomial model than for the binary model, and thus concludes that it is important to distinguish between hostile and agreed takeovers. However, he does not test which of the coefficients are significantly different across the two kinds of target, so it is unclear what his results really tell us about the differences between the two kinds of takeover. Further differences between the present study and Powell (1997) are: the use in this study of current replacement cost estimates of the capital stock rather than book values at historic cost; ${ }^{4}$ the focus on return-on-sales, dividends and Tobin's Q as measures of performance, rather than return-on-capital, which is unreliable given mismeasurement of the capital stock; the omission in Powell (1997) of macro variables, company age, and takeover speculation, which are all highly significant in the current study and which dominate cash flow, liquidity and net fixed assets (which are key variables in Powell's study); the use of both stock and flow measures of financial pressure; the reporting below of marginal effects rather than the unadjusted coefficients; ${ }^{5}$ the later sample period here (1989-96).

Dickerson-Gibson-Tsakalotos 1998 (henceforth 'DGT') use a sample of 892 quoted manufacturing companies over the period 1970-1991. The proportion of companies acquired in their sample is $36 \%$; no distinction is made between hostile and friendly takeovers. ${ }^{6}$ DGT estimate takeover hazard functions, which measure the effect of prebid characteristics on the conditional probability of being acquired at time $t$, conditional upon survival until time $t$. DGT argue that their methodology is superior to the logit approach since hazard functions can account for time-varying effects. This criticism is valid for cross-section logit models, but not for panel data logit models, where we can allow for duration effects in a flexible manner both at the aggregate level and at the company-specific level (as for example when we use company age dummies as a regressor). ${ }^{7}$

\footnotetext{
${ }^{4}$ The book value of capital at historic cost may be substantially below the (more economically relevant) current replacement cost for assets with long lifetimes, even at moderate rates of inflation (for a discussion see Blundell-Bond-Meghir, 1992, Section 17.2).

${ }^{5}$ As noted in Section 6 below, the marginal effects and the coefficients for multinomial logit models will generally differ, and may not even have the same sign.

${ }^{6}$ From reading DGT, it is not clear whether or not their sample includes any bankruptcies.

${ }^{7}$ Indeed the current study arguably uses more duration information than DGT. DGT's hazard approach conditions on the time alive in the dataset, but without conditioning on company age. The
} 
DGT restrict their sample to companies with a minimum of five years of available data. In the current paper we do not impose this restriction, and we find that the incidence of takeover is especially high in the early years (for example, up to five years since listing), and moreover that these takeovers appear to occur for distinct motives, namely financial synergies and IPO-to-sell-out. DGT's sampling restriction therefore risks missing these effects.

DGT find that the conditional probability of takeover is increasing in company size (measured by log real net assets), and is decreasing in the square of size, the proportion of tangible assets in total assets, profitability (the post-tax rate of return on net assets) and gross investment in tangibles (scaled by net assets). Leverage and gross pre-tax dividend yields have negative but insignificant effects on the probability of takeover. They find evidence of negative duration dependence; that is, a company is more likely to be acquired the older it becomes. Industry dummies are jointly insignificant, whether measured at the 2-digit SIC level or using a finer classification of 38 industrial groups based on Stock Exchange data. Although DGT construct measures of Tobin's Q, they do not include them as a regressor.

DGT and the current paper both find that the probability of takeover is decreasing in measures of company performance, and is not affected by dividends or industry factors. However, this paper does not find a significant role for investment or the proportion of tangible assets in total assets in the determination of takeover likelihood; this might be explained by our inclusion of Tobin's Q as a regressor, which turns out to be an important variable (more important also than profitability). In addition, unlike DGT we find that the probability of takeover is strongly decreasing in age; DGT's result is probably driven by their omission of young companies from their sample.

current study conditions on company age. Consider for example a company that has been present in the dataset for one year but that is twenty years old. DGT condition on the one year in the dataset, whereas the current study conditions on the twenty years. 


\section{Theories of Takeover: Empirical predictions}

\subsection{Motives for takeover}

For surveys of the possible motives for takeover, see Milgrom-Roberts (1992), Nickell (1995) and Shleifer-Vishny (1997). These surveys identify three distinct motives: managerial discipline, empire-building and synergy. We do not have space here to discuss these motives in detail; instead we focus on drawing out the empirical predictions.

The managerial discipline motive starts from observation that executives of large widely-held corporations may face only limited monitoring from shareholders, debtholders and product markets, and hence may enjoy considerable rents from the discretionary allocation of effort. There may then be an incentive for a hostile raider to tender an offer directly to the shareholders, to replace the incumbent management, and to extract the value gains from running the company more efficiently (Grossman-Hart, 1980). The main empirical prediction of the disciplinary motive for takeover is that the target underperforms prior to the bid. In addition, however, we would expect the disciplinary motive to be stronger when other control mechanisms-product-market competition (Schmidt 1997), financial pressure (Zwiebel 1996), direct monitoring by large shareholders (Shleifer and Vishny 1986) and the market for non-controlling share stakes (Zwiebel, 1995)-are less effective.

One form in which a manager can enjoy his rents from incumbency is in the acquisition of another company: this is the empire-building motive (Shleifer-Vishny 1988). There are no clear empirical implications for pre-bid target performance. Empirebuilding managers may target poorly-performing or strongly-performing companies, depending on their preference for a particular sector or product line. It is possible, but not certain, that the target will be in an unrelated sector. Empire-building acquisitions are most likely to occur when the manager has at his disposal a large amount of free cash flow. This in turn will be the case when other mechanisms for discipline are weak (so that for example ownership is dispersed and product-market competition is weak) and when the acquirer is performing well-either through skillful management or because of other factors, such as a macroeconomic boom. The post-bid implications for 
performance are clear: empire-building takeovers reduce value relative to other actions, such as returning free cash flow to shareholders.

Synergies exist when the value of two assets is greater when the assets are used in combination than separately. Synergies could come about through using two identical assets together (for example, market power or economies of scale), or two different assets (economies of scope). In a world of complete contracts there is no need for integration in order to benefit from synergies, since any such economies can be realised by writing a sufficiently detailed contract. However, when contracts are incomplete, integration may be optimal between two firms possessing complementary assets (Grossman-Hart 1986; Hart-Moore, 1990; Hart 1995).

It is difficult to relate the synergy motive to observables, since the complementarity or otherwise of assets is hard to measure objectively. However, we might have some expectation that companies that are driven to merge by synergy concerns are underperforming before takeover, since the motivation for the synergy is to increase productivity. In at least one extreme case there may be empirical implications, namely the case of financial distress. Typically this occurs when one firm is close to insolvency, and attempts to solicit a bid from a rescue company. The rescue company will buy the failing firm only if the price of the assets is low relative to the potential synergies. In this case we would expect the target to have poor performance, and to be under financial pressure. Performance should be reflected in profitability and Q measures, while financial pressure might be measurable through flow interest payments relative to earnings, or simply leverage. This has the opposite empirical prediction to Zwiebel (1996): rescue targets would be expected to have high indicators of financial pressure, while in Zwiebel (1996) strong financial pressure acts as a substitute for the takeover threat, so (hostile) targets should have weak indicators of financial pressure.

An important example of a kind of synergy that may drive merger is caused by financial constraints. Financial constraints exist when the cost of external sources of finance exceeds the cost of internal sources, and they are essentially caused by contracting imperfections due to asymmetric information (Stiglitz-Weiss 1981) or the inalienability 
of human capital (Hart-Moore 1994). Financial constraints bind, therefore, when not all positive NPV projects can be financed internally. In these circumstances there is a financial-synergy incentive for a firm that has positive free cash flow to merge with a firm which faces binding financial constraints. Empirically this might be manifested by acquirers being cash-rich and targets being small or strongly-performing.

Financial constraints suggest that takeover targets are likely to be small, for two reasons. First, if the bidder faces financial constraints then it is more difficult to finance a large acquisition than a small one. Second, smaller (and younger) firms may be more likely to be financially constrained, and thus become bid targets for financial synergy reasons.

\subsection{Takeover: Hostile or friendly?}

Takeover can proceed with the consent of the incumbent manager (friendly takeover) or without it (hostile takeover). It seems fair to assume that hostile takeover will be more costly for the raider than agreed takeover. Managers under threat of job-loss will resist the takeover through the exertion of entrenchment effort, for example in the form of instituting defence mechanisms (eg, poison pills), soliciting a white knight or demanding large golden parachutes.

Thus we would expect that for non-disciplinary motives takeover will be friendly, while for disciplinary motives it is more likely to be hostile. In empirical terms this means we should expect hostile targets to be poorly performing relative to friendly targets, while friendly targets should have the characteristics expected of synergy mergers.

\subsection{Implications for size, age and takeover speculation}

Should we expect takeover targets to be large or small companies? One reason suggests large and two small. To the extent that agency problems are more severe in larger companies, where ownership control is weaker, we might expect larger companies to underperform and thus to be more probable hostile takeover targets; of course we would expect this channel to work through underperformance, but to the extent that accounting data measure performance only imperfectly, there may still be a residual 
size effect. On the other hand, targets may be expected to be small firstly for financial synergy reasons, as outlined above, and secondly because, on the assumption that takeover defence has some fixed cost element, such as a fixed minimum fee for hiring investment bank advice, large companies will be better able to defend themselves. This second reason suggests that hostile targets will be smaller than friendly targets.

Three reasons suggest that targets will be younger than nontargets. First, financial synergies, as discussed above. Second, studies of market entry have found that there is a very high turnover amongst entrants (Geroski 1995), perhaps because prospective entrants face great uncertainty over the profitability from operating in a market-uncertainty that is resolved only once they have operated in the market for a period (Jovanovic 1982). That is, younger firms are more likely to go bankrupt, or at least experience financial distress, than older firms, and in consequence younger firms are more likely to solicit rescue bidders. Hence we expect agreed targets to be young and financially distressed.

The third reason is specific to age since stock market listing, rather than age since registration. This is especially of interest to us since our company birth and death data refer to birth and death on the London Stock Exchange, not on company registrations. Zingales (1995) argues that an initial owner who wishes to liquidate his wealth may have an incentive to go public in order to achieve the structure of ownership in the company that will maximize his total proceeds from its eventual sale. The idea is that the market for cash flow rights is more competitive for a quoted company than for a private company, and therefore that going public raises the price that can be expected from the sale of the company. ${ }^{8}$ For the purposes of the current study, the Zingales (1995) model alerts us to the possibility that some owners may seek a listing precisely

\footnotetext{
${ }^{8}$ Zingales (1995) argues that there are conditions under which private negotiation with a control buyer can yield higher expected revenues than an auction, in which case remaining private is optimal. However, this appears to be inconsistent with the Bulow-Klemperer (1996) results. Bulow and Klemperer (1996) prove under quite general conditions that an auction with no reserve price is a more profitable mechanism for selling an object than an optimally structured negotiation with one less bidder. Hence an auction between as few as two control buyers raises more expected revenue than direct negotiation with a single buyer. If an IPO gives the seller access to at least two control buyers, then the IPO maximizes revenue from control buyers as well as cash flow buyers. If the Bulow-Klemperer logic applies in this context, then the Zingales results underestimate the advantages of an IPO in terms of maximizing the revenue from a sell-out, unless there is only one control buyer in the economy.
} 
to facilitate a subsequent takeover (or to make the takeover terms more attractive for them). Hence there may be a group of recently-listed firms that have a high probability of being taken over. The Zingales model should be expected to apply more to friendly targets than hostile targets, since the initial owner goes public precisely to solicit a high bid from another company.

Suppose a company is a potential target for acquisition. Then we should expect takeover speculation in the financial press concerning this company to intensify, for two reasons. First, information may leak directly from the potential bidder to the press. Second, the financial press may itself determine that a particular company is a good candidate for acquisition, for example because it is poorly performing or because it has obvious synergies with another firm. If we were able to capture the characteristics of takeover targets perfectly with other data, such as accounting data, then takeover speculation would add no information and thus would have a coefficient insignificantly different from zero in a multiple regression with the other variables as the remaining regressors. However, to the extent that our accounting data give us insufficient information to identify targets perfectly, the financial press may provide a valuable additional information source.

We would expect information leakages to be less frequent in the case of hostile bids than friendly bids. A hostile bid will certainly raise the target's stock price at least for a period, so the potential bidder has a very strong incentive to conceal his intentions, or else the acquisition will immediately become much more expensive. This is not the case for friendly deals, where the target management does not compete with the raider over the appropriate value of the company. Hence we would expect takeover speculation to be more common for friendly acquisitions than hostile ones. In addition, to the extent that we expect speculation regarding hostile activity to be less reliable than that regarding friendly activity, we would expect friendly speculation to predict bids more accurately than its hostile counterpart.

Finally, consider the relationship between firm size and takeover speculation. We might expect that there is a size bias in press reporting, in the sense that speculation 
concerning large companies is more likely to appear in the financial press; in fact the univariate statistics of Section 5 bear out this expectation. This has two implications for multivariate modelling. First, it is important to control for firm size when examining the effect of speculation on takeover likelihood. To do this, we include both size and our measure of rumours as regressors. Second, we should include an interaction term to assess whether the explanatory power of rumours is greater or smaller for large firms. Hence we include as a separate regressor the product of firm size and rumour count.

\section{The Data}

Our initial sample is a panel of 767 nonfinancial companies that were listed on the London Stock Exchange in 1988. This represents roughly a third of the equities and half of the nonfinancial companies on the stock market at the time. The sample is approximately random; in fact it covers those companies whose names start with the letters A-L. In addition the sample excludes both nontrading (or shell) companies and large utilities such as British Gas. The data for the sample companies were drawn from the following sources. (See the Data Appendix for more details.)

Accounting data on the companies over the period 1981-1996 were taken from Datastream International. Price series for output by 2-digit SIC and for investment in buildings and in plant and machinery were taken from the Office for National Statistics (ONS). Macroeconomic variables such as unemployment and GDP were taken from the OECD Statistical Compendium. Each of the sample companies was allocated to a 2-digit SIC industry.

Basic acquisition information was taken from the 1997 London Share Price Database. Information collected included the identity of firms that were acquired, dates of acquisition and company birth dates. However, for takeovers the LSPD death date refers to the listing cancellation, which often occurs several months after the actual bid is accepted by the target shareholders. Hence for each takeover exit we checked the $F i$ nancial Times for the correct date of bid acceptance, and used this date as the death date. 
Finer information on acquisitions was collected from the Financial Times CD-ROM for 1988-95. In particular, information on takeover speculation came from this source. For each company in the sample a search was performed for the keywords 'speculation', 'rumours' or 'bid talk', and was cross-referenced with various merger keywords such as 'takeover', 'bid' and 'acquisition'. Each hit resulting from this search was read, and a unit observation recorded for each article in which a company was touted as a potential takeover target. For the purpose of statistical analysis, these date-specific observations were aggregated into a yearly count for each company.

The Financial Times was also used to distinguish between hostile and friendly targets. Following Morck-Shleifer-Vishny (1988), we classify a hostile bid as one where the initial reaction by the target management was to resist the takeover, even if later revised terms are accepted by the management. ${ }^{9}$ The two most important indications of a hostile takeover in the Financial Times were taken to be the incumbent management advising shareholders to reject the initial offer, or the incumbent management searching for a white knight.

A possible misclassification problem here is that a target management may-acting fully in the interests of their shareholders-resist the initial bid in an attempt to extract a higher price from the existing raider or to initiate an informal auction process for the target involving other potential bidders (De and Knez, 1993). ${ }^{10}$ In this case we would observe an initial bid being rejected but a revised bid being accepted, even though the bid is not hostile. To gain additional information we therefore read the articles in the Financial Times that described the progress of our sample bids. ${ }^{11}$ For each bid which

\footnotetext{
${ }^{9}$ Where the terms of the same bid were revised over time, we classified this as a single bid, dated by the initial bid. If the same company was the subject of more than one distinct bid over its lifetime, each bid is treated as separate.

${ }^{10} \mathrm{At}$ a theoretical level the difference between a hostile and friendly bid is that in the case of a hostile bid the incumbent management expects that takeover will lead to rent-loss, possibly via job-loss. It is precisely this threat of job-loss that disciplines the managers to work harder in models such as Schmidt (1997). However, it is not necessarily the case that job-loss results in a reduction of quasi-rents. If the manager has engaged in entrenchment effort that guarantees a large golden parachute, or if the manager can negotiate a perfectly compensating sum with the raider, then the manager suffers no loss of rents. The notion of a hostile takeover connotes rent loss, and thus implicitly assumes either a limit on entrenchment activities or on compensation by the raider. In the absence of these assumptions, we lose the disciplinary role of takeover risk: all takeovers are friendly.

${ }^{11}$ Nuttall (1999b) contains a Table providing brief excerpts from the Financial Times for each of the sample bids.
} 
we classified as hostile, there were almost always at least five articles in the Financial Times during the run-up to the bid and during the bid battle itself. In many cases the raider expressed hostile intent, in which the classification of the bid as hostile seemed most compelling. In most of the remaining bids classified as hostile there was evidence of resistance on the part of the target management that lasted beyond the initial bid. This could of course be explained by the negotiation motive, so there is a risk that some of our 'hostile' bids were in fact friendly.

Bids that did not meet the hostile-bid criteria were classified as being friendly. There is a danger here that hostile bids may be classified as friendly, since the bidder may negotiate the departure of the incumbent manager in return for a partially-compensating golden handshake (resulting in some, but not all, rents being lost) before the bid is announced, so that when the actual bid is announced there is no observed resistance by the incumbent management. For those bids which we classified as friendly there was often very little information reported in the Financial Times-typically just one entry recording the acceptance of the final bid terms. This probably reflects our findings below that friendly takeover targets are often small, and that there is a reporting bias against small firms. However, it seems likely that in several of these bids there was a degree of hostile intent, but that this information was simply not reported in the Financial Times.

Failed bids were identified using the Financial Times and the London Stock Exchange Quality of Markets Quarterly Review. We also classified failed bids as hostile or friendly, using the same classification scheme as for successful bids.

The Data Appendix describes the method used for computing replacement cost estimates of the capital stock, the process by which the investment series was compiled, and various 'cleaning' procedures that were applied to the data. These procedures reduced the sample from an initial 767 companies to 687 companies. Table 1 presents information on the sample incidence of corporate control events. For the period 1988-96 there were 201 takeover bids and 42 bankruptcies. Of the 201 takeover bids, two-thirds were friendly and one-third were hostile. As we would expect, the proportion of bids 
which failed is much higher for hostile bids (34\%) than for friendly bids (3.7\%).

\section{Descriptive statistics}

This paper focuses primarily on the multivariate analysis of the determinants of takeover, since a multivariate analysis controls for the interactions between the explanatory variables. Nevertheless, this section briefly presents some univariate descriptive statistics for our data. We divide the companies by corporate control event, where the possible events are successful friendly takeover, lapsed friendly takeover, successful hostile takeover, lapsed hostile takeover or bankruptcy. For ease of comparison, we also include a bid target category that groups together those companies that were the subject of a failed or successful takeover bid, whether the bid was friendly or hostile. We do not attempt to control for interactions between the variables; this is the purpose of the multivariate analysis carried out in Section 6.

Table 1 presents data on the sample incidence of takeover bids and bankruptcies. Of the 687 companies over the period 1988-96, 129 were acquired in a friendly takeover, five were the target of a lapsed friendly bid, 44 were acquired in a hostile takeover, 23 were the target of a failed hostile bid and 42 went bankrupt. In addition, two companies were the subject of both a failed and a successful hostile bid in the same accounting year, and two companies were the subject of failed bids in the year in which they went bankrupt. For each event route Table 2 presents summary statistics for some of the principal variables-size, age, takeover speculation, profitability, Tobin's Q, dividends, leverage and income gearing (see the Data Appendix Table for definitions of these-and other-variables). For those companies that were takeover targets or bankruptcies, the figures relate to the last full accounting year before the target or liquidation event. For those companies that were never the subject of a takeover attempt and which were alive at the end of the sample period (which we refer to in this section slightly inaccurately as 'nontargets'), the figures relate to the average over the observations.

The main findings from Table 2 are as follows. First, friendly acquireds and especially bankruptcies are small (in terms of employment) relative to nontargets, while 
hostile targets are large. Failed targets, and especially hostile ones, appear to be larger than successful-bid targets. Size appears to facilitate defence against a takeover bid. Overall, bid targets are smaller than nontargets, but are larger than bankruptcies.

Second, friendly acquireds and bankruptcies are younger than nontargets, while hostile targets appear to be about the same age as nontargets. Failed targets, especially hostile ones, tend to be older than successful bid targets. Bid targets taken together are younger than nontargets but older than bankruptcies.

Third, company performance. Takeover targets appear to have poorer return-onsales performance than nontargets. ${ }^{12}$ Bankruptcies have especially poor return-onsales performance, as we would expect. Takeover targets (especially hostile ones) and bankruptcies tend to have lower pre-bid Q values than nontargets. ${ }^{13}$ Friendly targets have lower dividends than alive firms, and bankruptcies have very low dividends indeed. ${ }^{14}$

Fourth, capital structure. Takeover targets (especially friendly ones) and bankruptcies have high leverage relative to nontargets. Table 2 also presents data on income gearing, defined as interest payments relative to earnings. Income gearing may be seen as a flow measure of the financial pressure on the company, and provides a complement to leverage, which may be seen as a stock measure of financial pressure. Table 2 reveals no clear patterns for the income gearing of different kinds takeover targets. As we would expect, bankruptcies have higher income gearing than nontargets, as do bid

\footnotetext{
${ }^{12}$ Throughout this study we use a net-of-depreciation return on sales measure rather than a cash flow returns measure (see the Data Appendix Table for definitions of these variables). The reason is that when we experimented with both variables in a general multivariate specification (see Section 6 below), return-on-sales was always more empirically informative than cash flow returns.

${ }^{13}$ Following the tradition of the finance literature (eg: Morck-Shleifer-Vishny 1988) this paper uses Tobin's Q as one measure of company performance. We measure Tobin's Q by the sum of the market value of equity and the book value of debt, divided by the current replacement cost of assets. A reduction in a company's share price will thus be reflected in a fall in Q, all else equal; this is the case for using average Q as a measure of company performance. However, as Nickell (1995) points out, there exist models in which differences in average $\mathrm{Q}$ across companies reflect factors other than performance differences. One firm could have a higher Q (marginal and average) than another firm because of superior investment opportunities that have not yet been fully exploited on account of adjustment costs. In addition, two companies with the same marginal Q could sustain different average Q simply because of differing degrees of diminishing returns (or market power), rather than differing degrees of performance.

${ }^{14}$ For our measure of dividen payout we use dividends-to-sales rather than dividends-to-profits or dividends-to-cash flow. This is because it is difficult to interpret dividends-to-profits or dividends-tocash flow given that the denominator may be negative or close to zero.
} 
targets taken in aggregate.

Table 3 summarizes the data we have collected for the incidence of press speculation about potential takeovers, measured by the number of takeover rumours concerning a given company reported in the Financial Times either in the last full accounting year before a target or bankruptcy event, or taken as an average for nontargets. Figure 1 shows that the rumour count is highly skewed, with over $75 \%$ of the sample companies never being the subject of takeover speculation in the Financial Times. Thus it is not surprising that the median number of rumours is zero for all event routes in Table 3.1. However, there is evidence that friendly acquireds, and even more so hostile targets, have a higher mean number of rumours in the final company year than do nontargets over the sample period. Bid targets as a whole experience a mean rumour frequency which is approximately five times greater than nontargets. Bankruptcies have a lower mean number of takeover rumours than all other event categories. Thus there is evidence that companies which are the subject of takeover bids are singled out by the financial press beforehand.

Table 3.2 shows that there is a strong positive association between the frequency of rumours and company size. This suggests that there is a size bias in the reporting in the Financial Times, in the sense that larger companies are more likely to be the subject of speculation. Of course this does not control for any relationship between size and performance, and thus the coefficient of rumour activity on takeover probability will have to be estimated in a multivariate model, as in Section 6 below. As a first step in this direction, however, Table 3.3 reports rumour incidence by exit route for small firms and large firms separately, where firms are categorized relative to median employment. From Table 3.3(a) we see that for small firms there is virtually no rumour activity, and little apparent relationship between rumours and exit route. For large firms, however, Table 3.3(b) shows that rumour incidence is particularly strong for acquired companies, and especially so for hostile acquireds. Hence a first look at the data on press speculation suggests that any relationship between exit route and rumour incidence should be conditioned upon firm size. 
To summarize, this section has examined univariate characteristics of the key variables in our sample. Relative to nontargets, bid targets are small, young, rumourintensive, and have low profitability, low Tobin's Q, low dividend payout and slightly higher leverage and income gearing. The findings for friendly targets are similar-which is not surprising given that two-thirds of our sample takeover bids are friendly. Relative to nontargets, hostile targets are large, rumour-intensive, and have low profitability and low Q; there are no clear differences for age, dividends and capital structure. Bankruptcies are small, young, unprofitable, and have low dividends and high income gearing.

\section{Multivariate Analysis: The Empirical Model}

The basic model used is a logit model of the form

$$
\mathrm{EVENT}_{t+1}=f(\text { target characteristics } t)
$$

where $\mathrm{EVENT}_{t+1}$ is a discrete variable that takes the value one if the company is the subject of a corporate control event in accounting year $t+1$, and takes the value zero otherwise. When we examine multinomial exit models, the dependent variable can take strictly positive integer values greater than one, depending on the number of event types.

There are two main kinds of corporate control event, namely takeover bid and liquidation. A takeover bid can be classified along two further dimensions: whether it is successful or unsuccessful; and whether it is hostile or friendly. Below we investigate all 'branches' of this classification 'tree'. Table 1 provides data on the sample incidence of corporate control events.

Note the timing of the dependent variable. Relative to the explanatory variables, the dependent variable takes on a nonzero value when there is a corporate control event in the next accounting year. Thus the model uses information up to and including the accounting year preceding the bid, but not in the accounting year of the bid itself. In the year of the bid itself there is no guarantee that accounting data will be available for the full year, and moreover even if they do exist the data may relate to a period after the bid actually takes place. 
Our data on takeover speculation start in 1988, so for our baseline takeover likelihood model, which uses the rumour data, the first year in which an exit event occurs is 1989. The last year in which an exit event occurs is 1996 (see Table 1). We will henceforth adopt the convention of describing a model's time period with reference to the dependent variable. In this section we estimate takeover likelihood models using the full sample period that contains rumour data; thus we estimate the models over the period 1989-1996. For this sample period there are 643 companies and, as we see from Table 1, 108 friendly bids and 49 hostile bids.

Now consider the appropriate explanatory variables. As is clear from Section 3, there are many variables that might be expected to affect the probability that a company is the subject of a corporate control event. For each EVENT variable set we began with a general specification, including a large number of explanatory variables. These variables included: employment, real sales, real capital, investment rate, dividends-tosales, return-on-sales, return-on-capital, Tobin's Q, leverage, income gearing, liquidity, takeover rumours, a rumours-size interaction term, age dummies, industry dummies, and year dummies. For each variable we experimented with lags of up to two periods, with growth as well as levels effects, with the variables squared, and with 2-digit SIC averages. For the age dummies, we found that the grouping which gave highest explanatory power was a three-way subdivision into those companies aged 1-5 years, those aged 6-9 years, and those aged 10 years and above. To avoid perfect collinearity we omit the $10+$ age group in the reported results. See the Data Appendix Table for a description of the variables.

Following extensive experimentation with the above list of variables-including application of rudimentary econometric techniques such as stepwise regression ${ }^{15}-$ we arrive at our preferred specification, which consistently has superior explanatory power over alternatives, regardless of the event dimension being examined. This set comprises: size (measured by log capital stock), performance (return-on-sales and Q), capital structure and financial pressure (measured by leverage and income gearing), age, incidence of takeover speculation and a size-rumours interaction term.

\footnotetext{
${ }^{15}$ See, for example, Greene (1997, Ch. 8).
} 
The following subsections examine different corporate control event classifications of the dependent variable. We begin by examining a basic multinomial logit model where companies are classified according to whether they exit the market via takeover or bankruptcy. Then we examine the takeover event more carefully, distinguishing first between failed and successful takeovers and then between hostile and friendly bids. In each case we use the same set of explanatory variables. This is both for ease of comparison across event dimensions and because, as noted above, we found one set of explanatory variables that consistently had explanatory power greater than alternatives. Year dummies are jointly significant in all cases, and thus are included in our regressions. However, we do not include industry dummies, since they were found to be individually and jointly insignificant whether measured at the 2-digit SIC level or at a more aggregated 15 -sector level. ${ }^{16}$ We also found that 2-digit industry averages of the time-varying explanatory variables were generally insignificant in these models. This might appear surprising, given that industry factors appear to be important in US studies. There are at least two possible explanations for why industry factors are generally unimportant in our data. ${ }^{17}$ First, at a theoretical level we would expect the determinants of takeover to be mostly company-specific rather than industry-specific. Second, the rather crude 2-digit SIC classification may capture only imprecisely the domain of common factors that do in fact impact upon a group of firms.

In our results we report the marginal effects (computed at the averages of the explanatory variables) in addition to the coefficients, since the marginal effects and the coefficients for multinomial logit models (which are nonlinear) will generally differ; indeed they need not have the same sign. ${ }^{18}$ We also report the Wald test of the null hypothesis that the marginal effects are jointly insignificantly different from zero, and the Likelihood Ratio Index for the regression. The Likelihood Ratio Index-which is also known as McFadden's (pseudo) R-squared-has recently been recommended by

\footnotetext{
${ }^{16}$ In their takeover hazard model using UK data, Dickerson-Gibson-Tsakalotos (1998) also find industry dummies to be insignificant.

${ }^{17}$ The exception is that sectoral income gearing enters as a significant coefficient in the hostiletakeover channel, as discussed in Section 6.3 below.

${ }^{18}$ See Greene (1997, Ch.19) for a discussion.
} 
Cameron-Windmeijer (1997) as a measure of goodness-of-fit for the logit model.

\subsection{Exit routes: Takeover versus Bankruptcy}

In this case there are three EVENT categories: the company is alive in the next accounting period; the company is the target of a successful takeover bid next period; and the company goes bankrupt in the next period. Table 4 reports the results.

Consider first the results for acquired companies. First, there is a negative effect of company size on the likelihood of being acquired; this effect is of similar magnitude whether the size variable is assets or sales, and whether the variable is in logarithm form or not. The effect is significant at the $10 \%$ level, and the significance level increases if any of the other key regressors are removed. For example, removing only the rumourssize interaction term alters the size marginal effect to -.0033 with a P-Value of 0.016. The negative effect of size on takeover likelihood is a well-known result in the literature (see, for example, Comment-Schwert 1995), although previous studies find a higher tstatistic. One possible explanation for this difference is that we include information that previous studies have not (in particular, the rumours data). The negative size marginal effect is consistent with a financial synergy motive for merger, as discussed in Section 3 above.

Secondly, the performance measures support the view that acquired companies have poor pre-bid performance. We have two performance measures, namely returnon-sales and Tobin's Q. Note that whenever we include Tobin's Q as a regressor, we also include leverage. We measure Tobin's Q as the sum of the market value of equity and the book value of debt, all divided by capital. Hence the marginal effect on $\mathrm{Q}$ measures the effect on takeover likelihood of market valuation for a given level of debt. When we include both Tobin's Q and return-on-sales as regressors, both marginal effects are negative, but the effect is strong for $Q$ and weak for return-on-sales. If we include either one of the variables but not the other, then the marginal effect on the included variable is strongly negative. This suggests two things. First, Tobin's $\mathrm{Q}$ and return-on-sales are capturing similar, but not identical, dimensions of company performance, and therefore act to some extent as substitutes in a multiple-regression 
framework. Second, with regard to explaining takeover likelihood, Q has greater power than return-on-sales. One key difference between $\mathrm{Q}$ and return-on-sales is that $\mathrm{Q}$ is a forward-looking measure (since it depends on the stock price), while return-on-sales is a purely backward-looking measure. Therefore we find some support for the view that acquired companies are selected more on the basis of forward-looking performance measures than retrospective ones.

The market valuation component of our $\mathrm{Q}$ variable is measured on the last day of the accounting year, so we need to check that $\mathrm{Q}$ is not capitalizing the value of an anticipated bid. ${ }^{19}$ In order to do this, we ran the same regression as in Table 4, except replacing company $\mathrm{Q}$ and sectoral $\mathrm{Q}$ with their corresponding values lagged one period. The results were very similar to those in Table 4 . In particular, the coefficient on company $\mathrm{Q}$ in the takeover exit route was -.0549 with a standard error of .0296, as compared with -.1249 with a standard error of .0464 in Table 4. Thus the negative effect of $\mathrm{Q}$ on the probability of takeover appears to be robust to extending the gap between share price data collection and bid dates beyond the range over which anticipation effects plausibly operate.

The negative effect of measured performance on takeover likelihood is consistent either with a managerial discipline interpretation or with underperformance driving merger-for-synergy. The underperformance effect could in an extreme form represent a rescue merger, in which case we should also expect to see signs of financial distress in rescue targets.

Third, leverage has a positive but weak effect on takeover probability. This is consistent with a financial distress motive for takeover; we would expect such takeovers to be primarily friendly since the manager of a failing firm has little incentive to resist a rescue bidder. The positive marginal effect on debt appears to be inconsistent with the Zwiebel (1996) theory of capital choice, whereby managers take on more debt in order

\footnotetext{
${ }^{19}$ Schwert (1996) studies pre-announcement stock price runups in 1814 successful and unsuccessful takeovers during 1975-91 of target firms listed on the New York Stock Exchange and the American Stock Exchange. He finds that cumulative abnormal returns to target firms' stock start to rise around day -42 (about two months before the bid announcment), with the largest pre-bid rise occurring from days -21 to -1 .
} 
to commit to work hard, thereby deterring the threat of takeover. However, this is not a definitive conclusion since this specification does not distinguish between hostile and agreed takeovers. In addition, there is no evidence that flow financial pressure, as measured by income gearing, affects takeover likelihood.

Fourth, there is a strong negative effect of age since listing on takeover likelihood. As discussed in Section 3 above, this could be because one motive for IPOs is to signal a desire to become acquired. Further corroboration of this Zingales (1995) effect will be found when we distinguish friendly and hostile takeovers.

Fifth, the marginal effect on takeover speculation is strongly positive. Consider the interpretation of this marginal effect. If one believed that rumours in the financial press simply reflect other observable takeover target characteristics-such as poor return-onsales performance-then the marginal effect on rumours should be strongly positive in a simple multinomial logit model where none of the other variables are present, but then should vanish once these other variables are added onto the right-hand side. If we run a multinomial logit regression on rumours alone, the marginal effect is indeed strongly positive. However, as Table 4 shows, the marginal effect remains significantly positive even when we introduce a range of accounting variables and year dummies. This suggests that the financial press is providing us with valuable information over and above that available from company accounts. By the same token, it suggests that company accounts data in themselves do not provide complete information for the prediction of which companies become acquired; of course this is not surprising.

In addition to including the rumour count, our models also include an interaction term which is the rumour count multiplied by company size (measured by the logarithm of real capital). From Table 4 we see that the interaction term is negative and significant at the $5 \%$ level. This suggests that conditional upon observing a takeover rumour in the financial press, the rumour is more likely to be followed by takeover the smaller the company in question. One possible explanation for this finding is as follows. Recall from Table 3.2 that larger firms are more likely than smaller firms to be the subject of takeover speculation in the financial press. Given this reporting bias in favour of large 
firms, smaller firms face a higher obstacle before they are reported on. Thus when a small firm does appear in the financial press, it is likely that there is an especially good reason for the speculation. One possible such reason is particularly compelling information regarding an impending takeover. If so, then information regarding small firms is on average more accurate than that regarding large firms.

We now illustrate how to gauge the economic significance of the marginal effects reported for the takeover exit route in Table 4 . Define as $p(x)$ the probability of takeover in our multinomial logit model with a vector of regressors $x$. Then the marginal effect with respect to a given regressor $x_{i}$ is $\frac{\partial p(x)}{\partial x_{i}}$. We can then compute the effect of a small change in an independent variable on the probability of takeover using the approximation $\Delta p \approx \frac{\partial p(x)}{\partial x_{i}} \Delta x_{i}$.

Consider, for example, the effect of an increase in Tobin's Q upon the probability of takeover. Our marginal effects are computed at the means of the independent variables, so we measure the change at the mean value of Q. Tobin's Q has a sample mean of 3.085, a standard deviation of 4.569, and a marginal effect of -.00281 (from Table 4). Thus an increase in $\mathrm{Q}$ of one standard deviation from the mean reduces the probability of takeover by approximately $0.0128(=.00281 \cdot 4.569)$. The predicted probability of takeover has a sample mean of .0326 and a standard deviation of .0461. Thus the one-standard-deviation increase in $\mathrm{Q}$ reduces the probability of takeover by $28 \%$ of a standard deviation. If the probability of takeover had previously been at its mean value, then the one-standard-deviation increase in Q reduces takeover risk by $39 \%$.

We now turn to the results on the determinants of bankruptcy likelihood. There is strong evidence that bankrupt companies have poor prior performance: both Tobin's $\mathrm{Q}$ and return-on-sales have negative marginal effects. Interestingly the return-on-sales effect is strong while the $\mathrm{Q}$ effect is weak, which is the exact converse of the case of acquisitions. This suggests that retrospective measures of company performance predict bankruptcy more accurately than forward-looking measures. This in turn suggests that financial distress (for example, shortage of current cash flow) rather than economic distress (that is, low NPV of company profits-also known as insolvency) is the 
driving force behind bankruptcy. This view is further corroborated by the marginal effect on leverage. The leverage term is positive and insignificant in the full specification of Table 4. However, when we omit return-on-sales from the specification the leverage marginal effect becomes significant at the $10 \%$ level. ${ }^{20}$ This suggests that bankrupt firms have both poor profitability performance and high gearing.

When is it appropriate to draw a distinction between financial distress and economic distress? In a world of perfect credit markets there is no such distinction. If a company with good prospects suffers a negative shock (such as an efficient umbrella producer experiencing unusually good weather), then the company can cover the resulting shortage of cash flow by borrowing on the credit market at a price equal to the social cost of funds. However, if credit markets are imperfect then a negative shock may result in bankruptcy even for a company with good prospects. Hence our finding that profitability predicts bankruptcy more strongly than Tobin's Q is consistent with the view that financial constraints are important for many poorly-performing companies.

Bankrupt companies are young on the stock market, which is consistent with the Jovanovic (1982) model discussed in Section 3 above. In addition, the marginal effects on rumours and rumour-size interaction take the same sign as for acquired companies, though the effects are slightly weaker. This suggests that when a company is the subject of a takeover rumour, both takeover and bankruptcy become more likely. This is consistent with the view that takeover speculation is identifying poorly-performing companies in general; of those companies that go on to exit the stock market, some are acquired and some are liquidated. This finding is supportive of the view that financial distress is frequently an important motive for acquisitions.

It will be noted that we have excluded dividends from our baseline specification of the exit likelihood models. The reason for this is that measures of dividend policy (such as dividends-to-sales and dividends-to-capital) are generally insignificant when we include as regressors our other measures of company performance (profitability and

\footnotetext{
${ }^{20}$ The income gearing marginal effect is positive, but is significant only if both profitability and age dummies are excluded from the set of explanatory variables. Perhaps surprisingly, therefore, our evidence indicates that stock measures of gearing dominate flow measures in explaining bankruptcy likelihood. However, both measures of gearing are dominated by profitability.
} 
Q). Nevertheless, the role of dividends is worthy of comment. If we run a parsimonious model with only time dummies and dividend-to-sales on the right-hand side, then dividend-to-sales enters negatively with a t-statistic of about -1.5. This provides some limited rationalization for the belief that raising dividends can be a takeover defence. However, when we add profitability and $\mathrm{Q}$ as regressors, then the marginal effect on dividend-to-sales becomes insignificant $(\mathrm{t} \approx 1)$. This suggests that dividends are capturing dimensions of performance which are measured more strongly by profitability and Q. The effects are similar, though slightly stronger, for bankruptcy likelihood.

The above findings on the determination of takeover likelihood in a multinomial logit model are similar to those we found in the univariate analysis of Section 5 . The main differences are in the size, profitability and dividends findings. In Section 5 we found that bid targets were young, unprofitable and have low dividend-to-sales. When we move to a multivariate framework these effects are still observable, but they are quite weak; this indicates that other variables (notably age, $\mathrm{Q}$ and rumours) have a more important role in explaining takeover likelihood. For bankruptcies the multivariate findings are similar to those of the univariate analysis, although the dividend and income gearing effects become weak.

\subsubsection{Hypothesis testing}

Wald tests reveal that the marginal effects on the takeover exit route are jointly significantly different from zero $\left(\chi^{2}[17]=121.32, \mathrm{P}=0.00\right)$, and the same is true for the bankruptcy exit route, though to a lesser extent $\left(\chi^{2}[17]=31.64, \mathrm{P}=0.028\right)$. The lower chi-square statistic for bankruptcies is not surprising given that there are only 40 liquidations in our sample, as compared with 134 takeovers. For the bankruptcy route the joint significance is completely driven by the return-on-sales and age variables: in

the presence of one of these variables the P-value on the Wald test is below 0.05 but in the absence of these variables it is 0.24 .

A Wald test also rejects the null hypothesis of equal marginal effects for acquired companies and bankruptcies $\left(\chi^{2}[17]=67.03, \mathrm{P}=0.00\right)$. This result is driven by differences in three of the variables: age, takeover rumours and Tobin's Q. In particular, 
the negative effect of age on exit likelihood is much stronger for takeovers than for liquidation. While the marginal effects on takeover rumours and Q take the same sign for both exit routes, the effects are again stronger for acquisitions than for bankruptcy.

\subsection{Takeover: Failed versus successful}

In this and the next subsection we examine more carefully the takeover dimension. We ignore the bankruptcy channel in these two sections, in the sense that we group bankrupt firms together with firms that were not the target of any takeover bid. Results do not change significantly if we reintroduce bankruptcy as a separate exit route in a multinomial logit model, or if we group bankrupt firms together with the targets of successful takeover bids.

In this section we ask: can the data distinguish between failed and successful takeovers? Table 5 presents the results of a multinomial logit model with two events: successful takeover and failed takeover. We find that the Age 6-9 Dummy model is poorly-identified, so we exclude it from this specification. The successful takeover channel is well-determined: ${ }^{21}$ the Wald test of the hypothesis that the successfulbid marginal effects are jointly insignificantly different from zero is strongly rejected $\left(\chi^{2}[17]=115.8, \mathrm{P}=0.00\right)$. We cannot reject the same hypothesis for the failedbid channel, though if we test a subset of these variables (size, Q, leverage, income gearing, age, rumours and rumour-size interaction) we do reject joint insignificance $\left(\chi^{2}[7]=14.0, \mathrm{P}=0.049\right)$. These findings are perhaps unsurprising given the smaller numbers here than in Sections 6.1 and 6.3 (namely, 134 successful bids and 23 failed bids).

There are, however, some interesting differences between failed and successful bids. We strongly reject the null hypothesis that the marginal effects on failed and successful bids are the same $\left(\chi^{2}[17]=95.6, \mathrm{P}=0.00\right)$. Three variables are individually different at the $1 \%$ level: rumours, age and size. A fourth variable, $\mathrm{Q}$, has a $\mathrm{P}$-value of 0.11 . The positive effect of rumours on the likelihood of takeover is much stronger for successful

\footnotetext{
${ }^{21}$ The results for successful takeovers here are similar to those in the specification of the previous section.
} 
bids than for failed bids. This is consistent with the evidence in Section 6.1 that firms must pass a 'hurdle' to become the subject of press reports, where one possible hurdle is that a takeover is particularly likely to occur successfully. Thus it is mainly bids that are sufficiently likely both to occur and to be successful that attract press coverage.

The hypothesis that young firms are more likely to be takeover targets is much more strongly supported for successful bids than for failed ones. This is consistent with the view that some recently listed companies may actively solicit bids from larger more-established firms. However, it is also consistent with the view that large size acts as a takeover defence. Some discrimination between these views will be possible when we examine the friendly/hostile split in Section 6.3.

Another interesting difference lies in the size effect. Whereas larger size makes a company less likely to become the target of a successful bid, it makes a company more likely to be the subject of a failed bid. This suggests that size acts as a takeover defence: large companies are better able to fend off takeover bidders. Of course to the extent that the information used in this study is publicly-available, we would expect bidders to be aware that large firms are better able to defend themselves against takeover bids, in which case we would not expect to observe costly failed bids; to the extent that learning is imperfect, however, it appears that size also acts as a defence against realised takeover bids.

Lastly, while Q has a significant and negative impact on the likelihood of becoming either a failed or a successful takeover target, the magnitude of the effect is much stronger for successful bids. This is consistent with the view that poor pre-bid performance attracts bidders, but that bidders will be prepared to attempt takeover only when they are sufficiently confident of success (takeovers involve high transaction costs, for example in the form of fees to investment banks).

To summarize the results of this section, the data enable us to distinguish between successful and failed takeover targets, though the failed-bid channel is less welldetermined than that for successful bids. There appear to be some interesting differences between the targets of failed and successful bids. Size acts as a defence mecha- 
nism, as does pre-bid performance. Takeover rumours are more likely to be followed by a successful bid than an unsuccessful one.

\subsection{Takeover: Friendly versus Hostile}

As discussed in Section 3, the distinction between friendly and hostile takeovers is central to the managerial discipline hypothesis: if the manager expects to lose rents after the bid then there is potentially a disciplinary effect, whereas if the manager expects to retain rents there is unlikely to be a disciplinary effect. Nuttall (1999a) examines whether the threat of friendly takeover and that of hostile takeover have different effects on company performance. The focus of attention here will be on the question of whether there exist any significant differences between the characteristics of companies that are the subject of hostile and friendly bids.

Our distinction between hostile and friendly bids is based on reports in the financial press as to whether the initial bid was rejected or not. As we discussed in Section 4, any scheme used to classify bids on the basis of press information is probably subject to error. However, on the basis of our reading of the Financial Times reports, we would expect that our scheme classifies too few bids as hostile.

Table 6 presents a model with friendly takeover and hostile takeover as the exit routes. Results are similar if we take the events to be friendly bid (whether failed or successful) and hostile bid (failed or successful), and if we introduce bankruptcy as a separate exit route. For the model in Table 6 the P-value on the Wald test of the hypothesis that the marginal effects are jointly insignificantly different from zero is 0.0000 for the friendly takeover route and 0.107 for the hostile takeover route. For hostile takeovers the P-Value falls to 0.04 if the time dummies are excluded (although the time dummies are jointly significant, the larger number of parameters requiring estimation reduces joint significance). The superior determination of the friendly takeover event is unsurprising, given that there are 31 hostile takeovers in the 1989-96 sample, as compared with 103 friendly takeovers. Not surprisingly, the results for the friendly takeover exit route are quite similar to those for the basic takeover route in Table 4.

The null hypothesis that the marginal effects are jointly equal across friendly and 
hostile takeovers is strongly rejected $\left(\chi^{2}[17]=74.0, \mathrm{P}=0.00\right)$. Further Wald tests reveal that this difference is driven by the age variables, though size, leverage and takeover rumours are also individually significantly different across the takeover types at the $6 \%$ level.

In particular, being young on the stock market has a much stronger positive effect on the likelihood of becoming a friendly target than a hostile target. This is further corroboration of the Zingales (1995) model, which predicts that managers wishing to sell their companies at a high price may undertake an IPO precisely in order to solicit a high bid.

Size has a strong and negative effect on the probability of being friendly-acquired, but an insignificant effect for hostile-acquired. This runs counter to the view that larger firms are better able to defend themselves against hostile takeovers. The negative size effect for friendly bids is consistent with a financial constraints view, whereby small firms have poorer access to external sources of finance, and thus have an incentive to merge with larger companies who do not face significant financial constraints. A further way of corroborating this hypothesis would be to see if friendly acquirers are large; our data do not contain this information, though from other studies of takeovers we know that in fact acquirers are typically several times larger than acquirees (eg, Morck-Shleifer-Vishny 1988).

Leverage has a strong and positive effect on the probability of being friendlyacquired, but not on the probability of being hostile-acquired. This lends further support to the view that financially distressed companies readily accept rescue bids. Only one financial pressure variable, namely industry income gearing, significantly affects the probability of being a hostile target, and it does so negatively. One explanation for this negative effect is that financial pressure acts as a substitute for the threat of hostile takeover, so that where there is greater financial pressure there is less likelihood of a hostile threat. This is consistent with the Zwiebel (1996) model, where managers take on debt to deter hostile takeover. However, we should treat this result with caution because we would expect the effect to operate at the company level rather 
than the industry level.

We find no significant difference in pre-bid performance (return-on-sales or Q) between friendly and hostile acquireds, although there appears to be underperformance in both cases. ${ }^{22}$ We have put forward several possible explanations for why friendly targets might be expected to have poor pre-bid performance. What can explain the finding in Table 6 that the probability of hostile takeover is decreasing in Tobin's Q? We suggest two explanations. First, to the extent that we believe that our classification scheme has selected those bids where the manager did in fact expect to lose rents, there is support for a disciplinary motive. Second, however, our classification scheme is subject to error, probably in the direction of classifying too few bids as hostile. If so, then some of the observed underperformance of 'friendly' bids may in fact reflect disciplinary effects. If we are wrong about the direction of classification bias, then the negative $\mathrm{Q}$ marginal effect on the hostile channel may capture to some extent the motives for friendly takeover-such as financial distress, financial synergies and selling-out.

Finally, takeover rumours positively affect the likelihood of being acquired with equal statistical significance whether friendly or hostile (a t-statistic of approximately 3). However, the size of the effect is much greater for friendly acquireds than for hostile acquireds. This is consistent with the view that there are much stronger incentives to contain leaks in the case of a hostile bid than a friendly one, so that public information would be expected to be less reliable for hostile bids.

Our findings for hostile and friendly acquireds with regard to age, profitability, and leverage are similar to those in the univariate analysis of Section 5. However, there are two main differences: in Section 5 we found that hostile acquireds are large, but size does not affect the probability of being hostile-acquired in the multivariate framework; and the univariate results suggest that hostile acquireds have lower Tobin's Q than friendly acquireds, but there is no such difference in the marginal effects of the multivariate model.

To summarize, the hostile takeover channel is reasonably well-determined in our

\footnotetext{
${ }^{22}$ This is consistent with the findings of Comment-Schwert (1997).
} 
model, though less well than the friendly takeover channel. There are notable differences between the characteristics that make friendly and hostile takeovers likely to occur, though they do not relate to pre-bid performance. Being stock market-young, small, highly leveraged or touted as a takeover target in the financial press has a much stronger positive impact on the probability of being friendly-acquired than on the likelihood of being hostile-acquired. These results are consistent with theories that predict that companies readily accept bids to sell out after going public, or in the case of financial distress. There is little support for the view that hostile targets have poorer pre-bid performance than friendly targets, though both kinds of targets experience poor pre-bid performance, as measured by Tobin's Q. Finally, there is some, albeit weak, evidence that greater financial pressure may act as a substitute for the threat of hostile takeover.

\section{Conclusion}

This paper has estimated takeover likelihood models for UK quoted companies, covering a sample of 643 companies over the period 1989-96. The variables we used to explain target likelihood were drawn from accounting data, share prices, macroeconomic series, and-a relatively novel source-reports in the financial press.

We found that takeovers, bankruptcy and survival are statistically distinguishable using our takeover likelihood models. Also distinguishable are failed versus successful takeover bids, and friendly versus hostile takeovers.

Bankruptcy likelihood is greater for companies with poor profitability, companies that are recently listed on the stock market, companies that are highly leveraged, and companies that are the subject of takeover rumours in the financial press. The fact that Tobin's Q-which is a forward-looking performance measure-has little explanatory power, is suggestive of the view that bankrupt companies are not always companies with a poor future, and thus that financial distress more than economic distress is the main driver of bankruptcy.

Several variables are important in explaining takeover likelihood, notably age since 
listing, takeover rumours, the rumour-size interaction, Tobin's Q, size and-to a lesser extent-leverage and return-on-sales. Takeover likelihood is decreasing in pre-bid performance, whether measured by Tobin's Q or profitability. This is evidence of the view that the market for corporate control selects underperforming companies as takeover targets, though it does not in itself give us precise information on the motives for acquisition. Highly geared companies are more likely to become acquired, which is consistent with a financial distress motive for takeovers. In addition, companies which are recently listed are much more likely to become acquired. Takeover likelihood is increasing in the incidence of takeover speculation in the financial press, but is decreasing in the size-rumours interaction. This suggests that the financial press is providing useful information over and above company accounts regarding companies that are likely to become acquired. The sign on the interaction term in consistent with the view that, given the reporting bias in favour of large companies, information regarding small companies must be especially accurate before attracting speculative comment. In contrast to several previous studies, we find that industry factors are not important for takeover likelihood, whether measured at the 2-digit SIC level or at a more aggregated level.

We find that friendly and hostile takeover likelihood have statistically distinct determinants. The age, size, leverage and rumour effects are much more pronounced for friendly takeovers than for hostile takeovers. There is some evidence that high industry financial pressure reduces the likelihood of hostile takeover. We find no evidence of differences in pre-bid Q and return-on-sales performance between friendly and hostile targets, although of course we find that both kinds of target appear to have poor pre-bid performance.

There were also some significant differences between the determinants of successful and failed bids. The positive effect of rumours on the likelihood of takeover is much stronger for successful bids than for failed bids, suggesting that financial speculation focuses on companies that are especially clear candidates for acquisition. Being young raises the relative probability of successful versus failed takeover, suggesting that young firms are especially defenceless against takeover attempts. Whereas larger size makes a 
company less likely to be the target of a successful bid, it makes a company more likely to be the subject of a failed bid. This suggests that size acts as a takeover defence: large companies are better able to fend off takeover bidders. While Q has a significant and negative impact on the likelihood of becoming either a failed or a successful takeover target, the magnitude of the effect is much stronger for successful bids, suggesting that good Q-performance also acts as a defence mechanism against takeover bids.

What are the implications of these results for theories of takeover? For friendly takeover targets, we found support for three motives: financial distress; financing synergies; and the Zingales (1995) IPO-to-sell-out model. Evidence for financial distress as a motive comes from the combination of high leverage with poor pre-bid performance in friendly targets. Evidence for financing synergies comes from the fact that friendly targets are likely to be small, highly leveraged, and underperforming. The Zingales model is supported by the fact that companies that have been quoted for only a short period of time are far more likely to be acquired than older companies, particularly via friendly takeovers.

With regard to hostile targets, the poor pre-bid performance combined with the insignificance of financial pressure variables is consistent with the disciplinary view that takeover raiders select underperforming companies for acquisition. However, we find no evidence that pre-bid performance differs as between friendly and hostile targets.

We also found some, admittedly not very strong, evidence that the threat of hostile takeover and financial pressure are substitutes, since greater industry financial pressure was associated with a lower likelihood of hostile (but not friendly) bidding. This complements the results of Nickell-Nicolitsas-Dryden (1997), who provide evidence that product-market competition, internal monitoring and financial pressure are substitute forms of managerial discipline.

Apart from shedding light on theories of takeover, the takeover likelihood models used in this paper can be valuable in providing a quantitative measure of the intensity of the threat of takeover. For an analysis of the effects of the threat of takeover on company performance using these measures, see Nuttall (1999a). 
In closing we mention a data-related limitation of the current study. Perhaps the most significant omission as a potential explanatory variable was a measure of excess stock market returns. We did include Tobin's Q, which incorporates a measure of the market value of equity. In addition, the evidence from the existing studies is that $\mathrm{Q}$ and excess returns seem to have similar effects on takeover likelihood (Palepu, 1986; Comment-Schwert, 1995). Nevertheless, it would be an interesting extension to include a measure of excess returns. 


\section{Data Appendix}

Most of the accounting items were taken directly from Datastream, as described in the Data Appendix Table. Adjustments were made to obtain a consistent series for investment, and to estimate the net capital stock at replacement cost.

Our measure of investment records gross fixed investment. For the period up to and including 1991 we use ds435, which was Datastream's total new fixed assets variable, from the sources and uses accounts. This variable is the sum of ds431 (flow of expenditure on gross direct purchases of fixed assets) and ds432 (the book value of gross acquisitions of fixed assets). Following the change in UK accounting procedures in 1991, ds431 is relabelled ds1024 and ds432 is no longer available. In place of ds432 we use $\max [0, \mathrm{ds} 479]$, where ds479 is as ds432, except net of the book value of divestments of fixed assets.

Our capital stock variable $p_{t}^{K} K_{i t}$ is a replacement cost estimate of net fixed assets at current prices, where $p_{t}^{K}$ is an implicit price deflator for capital goods. We take the book value of net fixed assets (ds339) in the first sample year for a company, and adjust for pre-sample capital goods price inflation making the assumption that all capital is three years old. The ds339 variable comprises land, buildings, plant and machinery, and excludes inventories. For subsequent years we allow for depreciation and inflation according to the perpetual inventory formula

$$
p_{t+1}^{K} K_{i t+1}=\left[(1-\delta) p_{t}^{K} K_{i t}\right] \frac{p_{t+1}^{K}}{p_{t}^{K}}+p_{t+1}^{K} I_{i t+1}
$$

with $\delta=0.08$, where $p_{t}^{K} I_{i t}$ is gross fixed investment, as described above. I thank Steve Bond for providing the Fortran program that computes this formula.

The investment price series $p_{t}^{K}$ is formed using Office for National Statistics (ONS) data as the weighted sum of price series for buildings and for plant/machinery, where the weights reflect the respective shares in aggregate investment.

Our 2-digit SIC output price series, taken from ONS publications, was kindly provided by Daphne Nicolitsas. Firms were allocated to SIC groups based on their Stock Exchange sector classification. 
Our initial sample is a panel of 767 nonfinancial companies that were listed on the London Stock Exchange in December 1987, and that did not die before June 1988. Various 'cleaning' procedures were applied to the data. Companies with the following data characteristics were removed entirely from the dataset: companies with fewer than two observations; companies with missing series on key variables (such as sales revenue and employment); and companies with fewer than 50 employees. These procedures reduced the sample from an initial 767 companies to 687 companies. Our rumours data begin in 1988; this further reduces the sample from 687 to 643 companies.

Implausible employment observations were replaced by figures from Extel where possible. ${ }^{1}$ We also examined series with large jumps in the key production function variables, namely sales, employment and the capital stock. The standard approach is to exclude companies with large jumps (for example year-on-year changes of a factor exceeding three). Whilst this approach may be sensible for some empirical questions, it does not seem appropriate here because if two companies merge then we would fully expect sales, employment and capital to increase, possibly by a large amount. Thus we looked for jumps in ratios between the key variables, namely the ratios of salesto-labour, capital-to-sales, and capital-to-labour. The logarithms of these ratios are roughly symmetrically distributed, and a jump of a factor of three in the ratio itself corresponds approximately to a change in the logarithm of the ratio of at least five standard deviations from the mean. Sixty-six companies had changes of more than a factor of three in these ratios at some point during the sample period. In each case we assessed whether the jumps were implausible (for example with reference to reports in the Financial Times), and if so we excluded the appropriate series.

Observations on accounting year periods of less than 11 months or more than 13 months were removed. Only consecutive yearly observations were kept. If an accounting year in a company's series was either missing or relates to a financial year that is shorter than 11 months or longer than 13 months, then the observation was removed,

\footnotetext{
${ }^{1}$ We use Datastream rather than Extel as our primary source of accounting data because Extel generally removes dead companies soon after exit, while Datastream provides reasonably full coverage of dead firms (at least for our period of interest, namely 1989-96). For a study of takeovers, this is obviously a decisive factor in Datastream's favour.
} 
and the longer post-1988 series was kept. For example, suppose a company reports in accounting years 1988-95, but that the 1990 observation is either missing or relates to a non-12-month period. Then we removed the 1988-90 observations, but kept the 1991-95 series. Thus although all of our companies were listed on the London Stock Exchange in January 1988, the data series for some of our companies do not begin until after 1988. This explains the fact that in Column 1 of Table 1 there are only 579 companies with data for 1988, even though there were 687 companies in our sample.

Details of which firms were the subject of successful takeover bids were obtained from the London Share Price Database, which records company exits, death date, and reason for exits. However, for takeovers the LSPD death date refers to the listing cancellation, which often occurs several months after the actual bid is accepted by the target shareholders. Hence for each takeover exit we checked the Financial Times for the correct date of bid acceptance, and used this date as the death date.

The LSPD also provides a Stock Exchange sector classification variable. Scott Evans kindly provided an algorithm that maps this classification into a 2-digit SIC industry code. We used this algorithm to allocate each of our companies to a 2-digit SIC industry.

For the purposes of data analysis, it was necessary to create a 'year' variable for each observation. If a company's financial year ends between January and June, then this observation is classified as belonging to the previous calendar year; if a company's financial year ends between July and December, then this observation is classified as belonging to the current calendar year. For example, consider a company whose financial year ends in January. Then data from company accounts (for example, sales, employment, debt etc) for the 12 month period ending in January 1988 are classified as 1987 data by our 'year' variable. However, for a company whose financial year ends in December, data from company accounts that are reported in December 1988 are classified as 1988 by our 'year' variable.

Information on takeover speculation was taken from the Financial Times CD-ROM for $1988-95 .^{2}$ For each company in the sample a search was performed for the keywords

\footnotetext{
${ }^{2}$ The Financial Times CD-ROM is not available for years before 1988 .
} 
'speculation', 'rumours' or 'bid talk', and was cross-referenced with various merger keywords such as 'takeover', 'bid' and 'acquisition'. Each hit resulting from this search was read, and a unit (date-specific) observation recorded for each article in which a company was touted as a potential takeover target. ${ }^{3}$ For the purpose of regression analysis, these date-specific observations were aggregated into a yearly count for each company. ${ }^{4}$ We found that grouping all observations where there were 3 or more rumours gave a slightly improved fit compared to using the raw rumour count variable, reflecting the fact that the distribution of the rumour count is very skewed (see Figure 1). Hence in the reported regression analysis we used a specification where values 0,1,2,3 correspond to 0 rumours, 1 rumour, 2 rumours and 3 or more rumours respectively. However, all our results were robust to alternative specifications of the measure of rumours.

\footnotetext{
${ }^{3}$ We also distinguished 'serious' from 'less serious' speculation, where serious speculation names a bidder as well as the target; this distinction proved to be uninformative in the regression analysis.

${ }^{4}$ Consistent with the use of company accounts data in the study, this yearly count refers to the accounting year of each company, not the calendar year.
} 
Data Appendix Table: Description of Variables

\begin{tabular}{|c|c|c|}
\hline Variable & Description & Source \\
\hline Sales Revenues & ds104 & Datastream \\
\hline Log Real Sales & $\begin{array}{l}\text { ds104 deflated by a 2-digit SIC } \\
\text { output price series, in logs }\end{array}$ & $\begin{array}{l}\text { Datastream; Office for National } \\
\text { Statistics. }\end{array}$ \\
\hline Employment & Log of ds 219 & $\begin{array}{l}\text { Datastream, replaced with Extel } \\
\text { data where appropriate. }\end{array}$ \\
\hline Capital stock & $\begin{array}{l}\text { Replacement cost estimate of the } \\
\text { capital stock }\end{array}$ & Datastream (see Data Appendix) \\
\hline Real Capital Stock & $\begin{array}{l}\text { Capital stock deflated by } \\
\text { investment price series, in logs }\end{array}$ & ONS \\
\hline Investment level & Gross investment & Datastream (see Data Appendix) \\
\hline Profits & $\begin{array}{l}\text { Profits net of interest, taxes and } \\
\text { depreciation, gross of dividends } \\
\text { (ds182) }\end{array}$ & Datastream \\
\hline Return-on-sales & Profits/ds 104 & \\
\hline Return-on-capital & Profits/Capital stock & \\
\hline Cash flow & $\begin{array}{l}\text { Profits net of interest and taxes } \\
\text { plus depreciation (ds182+ds136) }\end{array}$ & Datastream \\
\hline $\begin{array}{l}\text { Cash flow return-on- } \\
\text { sales }\end{array}$ & Cash flow/Sales & \\
\hline Dividend level & ds 187 & Datastream \\
\hline Dividends-to-sales & ds187/ds104 & \\
\hline Leverage & $\begin{array}{l}\text { Debt-Capital Ratio } \\
\text { (ds321/Capital stock) }\end{array}$ & $\begin{array}{l}\text { Datastream. } \\
\text { Debt is at book value. }\end{array}$ \\
\hline Tobin's Q & (ds321+HMV)/Capital stock & $\begin{array}{l}\text { Datastream. } \\
\text { HMV is market valuation of } \\
\text { equity on the last day of the } \\
\text { accounting year. }\end{array}$ \\
\hline Income gearing & $\begin{array}{l}\text { Interest payments relative to } \\
\text { earnings } \\
(\mathrm{ds} 153 /(\mathrm{ds} 153+\mathrm{ds} 157+\mathrm{ds} 136))\end{array}$ & Datastream \\
\hline Age & $\begin{array}{l}\text { Measured in years from listing on } \\
\text { London Stock Exchange }\end{array}$ & London Share Price Database. \\
\hline Liquidity & $\begin{array}{l}\text { Total cash and equivalent } \\
\text { deflated by the capital stock } \\
\text { (ds375/Capital stock) }\end{array}$ & Datastream. \\
\hline Rumours & $\begin{array}{l}\text { Annual count of number of } \\
\text { articles reporting takeover } \\
\text { speculation on the company in } \\
\text { question; see Data Appendix. }\end{array}$ & $\begin{array}{l}\text { Financial Times CD-ROM } \\
\text { 1988-95. }\end{array}$ \\
\hline
\end{tabular}




\section{Tables}

Table 1: Sample Incidence of Corporate Control Events

\begin{tabular}{|c|c|c|c|c|c|c|c|}
\hline Year & $\begin{array}{c}\text { Number } \\
\text { of } \\
\text { companies }\end{array}$ & $\begin{array}{c}\text { Friendly } \\
\text { takeovers }\end{array}$ & $\begin{array}{c}\text { Failed } \\
\text { friendly } \\
\text { bids }\end{array}$ & $\begin{array}{c}\text { Hostile } \\
\text { takeovers }\end{array}$ & $\begin{array}{c}\text { Failed } \\
\text { hostile } \\
\text { bids }\end{array}$ & $\begin{array}{c}\text { Bid targets } \\
\text { overall }\end{array}$ & Bankruptcies \\
\hline 1988 & 579 & 26 & 0 & 13 & 5 & 44 & 2 \\
\hline 1989 & 550 & 26 & 1 & 10 & 6 & 43 & 10 \\
\hline 1990 & 526 & 21 & 3 & 7 & 3 & 34 & 11 \\
\hline 1991 & 508 & 19 & 0 & 2 & 3 & 24 & 8 \\
\hline 1992 & 495 & 7 & 0 & 3 & 3 & 13 & 6 \\
\hline 1993 & 483 & 6 & 1 & 0 & 0 & 7 & 1 \\
\hline 1994 & 462 & 6 & 0 & 2 & 2 & 10 & 3 \\
\hline 1995 & 438 & 12 & 0 & 6 & 1 & 19 & 1 \\
\hline 1996 & 59 & 6 & 0 & 1 & 0 & 7 & 0 \\
\hline Totals & & 129 & 5 & 44 & 23 & 201 & 42 \\
\hline
\end{tabular}

Notes:

1. Observations on accounting years are allocated to the current calendar year if the accounting year ends in July-December, and to the preceding calendar year if the accounting year ends in January-June. See also the Data Appendix for a description of the 'year' variable.

2. At time of sampling, only 59 companies had company accounts reported by Datastream for 1996. 
Table 2: Univariate Descriptive Statistics

Sample means (with standard deviations in parentheses)

\begin{tabular}{|c|c|c|c|c|c|c|c|}
\hline & $\begin{array}{l}\text { Alive } \\
\text { nontargets }\end{array}$ & $\begin{array}{l}\text { Friendly } \\
\text { acquireds }\end{array}$ & $\begin{array}{l}\text { Lapsed } \\
\text { friendly } \\
\text { targets }\end{array}$ & $\begin{array}{l}\text { Hostile } \\
\text { acquireds }\end{array}$ & $\begin{array}{l}\text { Lapsed } \\
\text { hostile } \\
\text { targets }\end{array}$ & $\begin{array}{l}\text { Bankrupt- } \\
\text { cies }\end{array}$ & $\begin{array}{l}\text { All bid } \\
\text { targets }\end{array}$ \\
\hline $\begin{array}{l}\text { Observa- } \\
\text { tions }\end{array}$ & 3813 & 129 & 5 & 44 & 21 & 40 & 199 \\
\hline $\begin{array}{l}\text { Employ- } \\
\text { ment }\end{array}$ & $\begin{array}{c}6635 \\
(17295) \\
\end{array}$ & $\begin{array}{c}2482 \\
(5366) \\
\end{array}$ & $\begin{array}{c}3698 \\
(2758) \\
\end{array}$ & $\begin{array}{c}9312 \\
(20435) \\
\end{array}$ & $\begin{array}{c}19852 \\
(48410) \\
\end{array}$ & $\begin{array}{c}1379 \\
(2158) \\
\end{array}$ & $\begin{array}{c}5856 \\
(19420) \\
\end{array}$ \\
\hline $\begin{array}{l}\text { Years } \\
\text { since } \\
\text { listing }\end{array}$ & $\begin{array}{c}37.3 \\
(27.4)\end{array}$ & $\begin{array}{c}24.5 \\
(24.0)\end{array}$ & $\begin{array}{c}36.8 \\
(37.8)\end{array}$ & $\begin{array}{c}34.7 \\
(21.3)\end{array}$ & $\begin{array}{c}47.1 \\
(26.8)\end{array}$ & $\begin{array}{c}19.8 \\
(23.5)\end{array}$ & $\begin{array}{c}29.4 \\
(25.1)\end{array}$ \\
\hline $\begin{array}{l}\text { Return- } \\
\text { on-Sales }\end{array}$ & $\begin{array}{l}.041 \\
(.068)\end{array}$ & $\begin{array}{l}.032 \\
(.059)\end{array}$ & $\begin{array}{l}.008 \\
(.052)\end{array}$ & $\begin{array}{c}.032 \\
(.032)\end{array}$ & $\begin{array}{c}.033 \\
(.057)\end{array}$ & $\begin{array}{l}-.014 \\
(.098)\end{array}$ & $\begin{array}{l}.032 \\
(.053)\end{array}$ \\
\hline Tobin's Q & $\begin{array}{l}3.31 \\
(5.6) \\
\end{array}$ & $\begin{array}{l}2.98 \\
(3.6) \\
\end{array}$ & $\begin{array}{l}1.51 \\
(.8)\end{array}$ & $\begin{array}{l}2.14 \\
(1.5) \\
\end{array}$ & $\begin{array}{l}1.79 \\
(1.0) \\
\end{array}$ & $\begin{array}{l}3.16 \\
(7.5) \\
\end{array}$ & $\begin{array}{l}2.63 \\
(3.1) \\
\end{array}$ \\
\hline $\begin{array}{l}\text { Dividends- } \\
\text { to-sales }\end{array}$ & $\begin{array}{c}.0208 \\
(.01926) \\
\end{array}$ & $\begin{array}{c}.0188 \\
(.02062) \\
\end{array}$ & $\begin{array}{c}.0114 \\
(.01138) \\
\end{array}$ & $\begin{array}{c}.0201 \\
(.01260) \\
\end{array}$ & $\begin{array}{c}.0195 \\
(.01328) \\
\end{array}$ & $\begin{array}{c}.0082 \\
(.01205) \\
\end{array}$ & $\begin{array}{c}.0190 \\
(.01821) \\
\end{array}$ \\
\hline Leverage & $\begin{array}{l}.27 \\
(.66) \\
\end{array}$ & $\begin{array}{c}.38 \\
(1.3)\end{array}$ & $\begin{array}{l}.29 \\
(.17)\end{array}$ & $\begin{array}{c}.21 \\
(.17)\end{array}$ & $\begin{array}{c}.29 \\
(.23) \\
\end{array}$ & $\begin{array}{l}.32 \\
(.40)\end{array}$ & $\begin{array}{c}.33 \\
(1.1)\end{array}$ \\
\hline $\begin{array}{l}\text { Income } \\
\text { gearing }\end{array}$ & $\begin{array}{c}.16 \\
(16.2)\end{array}$ & $\begin{array}{l}.17 \\
(.68)\end{array}$ & $\begin{array}{c}.53 \\
(.44)\end{array}$ & $\begin{array}{c}.72 \\
(5.9)\end{array}$ & $\begin{array}{c}.47 \\
(.75)\end{array}$ & $\begin{array}{l}.35 \\
(.73)\end{array}$ & $\begin{array}{c}.02 \\
(2.8)\end{array}$ \\
\hline
\end{tabular}


Table 3: Rumour Incidence

Note: Table 3 refers to data from 1989-96.

Table 3.1: Rumours and exit

\begin{tabular}{|l|r|r|r|r|}
\hline & \multicolumn{4}{|c|}{ Number of Rumours } \\
\hline \multicolumn{1}{|c|}{ Control Event } & Observations & \multicolumn{1}{|c|}{ Median } & \multicolumn{1}{c|}{ Mean } & \multicolumn{1}{c|}{ Std. Dev. } \\
\hline Alive nontargets & 3372 & 0 & .18 & 1.3 \\
\hline Friendly acquireds & 103 & 0 & .47 & 2.7 \\
\hline Lapsed friendly targets & 5 & 0 & 0 & 0 \\
\hline Hostile acquireds & 31 & 0 & 2.23 & 4.8 \\
\hline Lapsed hostile targets & 17 & 0 & 1.18 & 3.0 \\
\hline Bankruptcies & 38 & 0 & .08 & .27 \\
\hline All bid targets & 156 & 0 & .88 & 3.3 \\
\hline
\end{tabular}

Table 3.2: Rumours and company size

\begin{tabular}{|c|r|r|r|r|}
\hline & \multicolumn{4}{|c|}{ Employment } \\
\hline Rumours per year & Observations & Median & Mean & Std. Dev. \\
\hline 0 & 3823 & 1012 & 5548 & 15634 \\
\hline 1 & 125 & 6335 & 16619 & 27687 \\
\hline 2 & 51 & 4600 & 16072 & 26407 \\
\hline 3 & 26 & 4564 & 19813 & 34140 \\
\hline$>=4$ & 75 & 17178 & 34566 & 36995 \\
\hline
\end{tabular}


Table 3.3: Rumours and exit, for small and large firms

Small firms have below-median employment; Large firms have above-median employment. Median company employment in 1989-96 was 1112.

Table 3.3(a): Rumours and exit, for small firms

\begin{tabular}{|l|r|r|r|r|}
\hline & \multicolumn{4}{|c|}{ Rumours } \\
\hline \multicolumn{1}{|c|}{ Control Event } & Observations & \multicolumn{1}{|c|}{ Median } & Mean & Std. Dev. \\
\hline Alive nontargets & 1714 & 0 & .03 & .38 \\
\hline Friendly acquireds & 57 & 0 & .09 & .47 \\
\hline Lapsed friendly targets & 2 & 0 & 0 & 0 \\
\hline Hostile acquireds & 11 & 0 & 0 & 0 \\
\hline Lapsed hostile targets & 4 & 0 & 0 & 0 \\
\hline Bankruptcies & 25 & 0 & .08 & .28 \\
\hline All bid targets & 74 & 0 & .07 & .41 \\
\hline
\end{tabular}

Table 3.3(b): Rumours and exit, for large firms

\begin{tabular}{|l|r|r|r|r|}
\hline & \multicolumn{4}{|c|}{ Rumours } \\
\hline \multicolumn{1}{|c|}{ Control Event } & Observations & \multicolumn{1}{|c|}{ Median } & \multicolumn{1}{c|}{ Mean } & \multicolumn{1}{c|}{ Std. Dev. } \\
\hline Alive nontargets & 1658 & 0 & .33 & 1.8 \\
\hline Friendly acquireds & 46 & 0 & .93 & 3.9 \\
\hline Lapsed friendly targets & 3 & 0 & 0 & 0 \\
\hline Hostile acquireds & 20 & 1 & 3.5 & 5.6 \\
\hline Lapsed hostile targets & 13 & 0 & 1.5 & 3.3 \\
\hline Bankruptcies & 13 & 0 & .07 & .27 \\
\hline All bid targets & 82 & & 1.6 & 4.4 \\
\hline
\end{tabular}




\section{Table 4: Exit likelihood model: Takeover versus Bankruptcy}

Multinomial logit regression.

Sample period is 1989-96. Number of observations $=4100$.

Log Likelihood $=-697.38$. Likelihood Ratio Index $=0.1431$

Coefficients. $\chi^{2}(34)=232.94 ; \mathrm{P}-$ Value $=0.0000$.

\begin{tabular}{|c|c|c|c|c|c|c|}
\hline & \multicolumn{3}{|c|}{ Acquired Companies } & \multicolumn{3}{|c|}{ Liquidations } \\
\hline Variable & Coefficient & \begin{tabular}{|c|} 
Standard \\
error
\end{tabular} & P-Value & Coefficient & $\begin{array}{c}\text { Standard } \\
\text { error }\end{array}$ & P-Value \\
\hline Log Real Capital Stock & -.1064 & .0655 & 0.10 & -.0970 & .1244 & 0.44 \\
\hline Return-on-Sales & -1.8343 & 1.2406 & 0.14 & -5.3720 & 1.1289 & 0.002 \\
\hline $\mathrm{Q}$ & -.1249 & .0464 & 0.005 & -.1016 & .0716 & 0.16 \\
\hline Sectoral Q & .0403 & .0723 & 0.58 & .0823 & .1346 & 0.54 \\
\hline Leverage & .2541 & .1676 & 0.12 & .2449 & .2306 & 0.30 \\
\hline Sectoral Leverage & .0111 & .6495 & 0.98 & .0194 & 1.0417 & 0.98 \\
\hline Income Gearing & .0015 & .0058 & 0.84 & .0829 & .0742 & 0.28 \\
\hline Sectoral Income Gearing & -.0053 & .0079 & 0.49 & .0495 & .2894 & 0.86 \\
\hline Takeover Rumours & 1.7142 & .5078 & 0.001 & 3.7951 & 1.6580 & 0.03 \\
\hline Rumour-Size Interaction & -.1351 & .0674 & 0.05 & -.5304 & .2933 & 0.07 \\
\hline Age 1-5 Years Dummy & 3.3536 & .3665 & 0.000 & 4.3642 & .4992 & 0.000 \\
\hline Age 6-9 Years Dummy & 1.1909 & .2450 & 0.00 & 1.6739 & .4290 & 0.003 \\
\hline
\end{tabular}

Marginal effects. $\chi^{2}(34)=151.37$ P-Value $=0.0000$.

\begin{tabular}{|l|r|r|r|r|r|r|}
\hline & \multicolumn{2}{|c|}{ Acquired Companies } & \multicolumn{3}{c|}{ Liquidations } \\
\hline \multicolumn{1}{|c|}{$\begin{array}{c}\text { Marginal } \\
\text { effect }\end{array}$} & $\begin{array}{c}\text { Standard } \\
\text { error }\end{array}$ & P-Value & $\begin{array}{c}\text { Marginal } \\
\text { effect }\end{array}$ & $\begin{array}{c}\text { Standard } \\
\text { error }\end{array}$ & P-Value \\
\hline Log Real Capital Stock & -.0023 & .0014 & 0.10 & -.0004 & .0005 & 0.44 \\
\hline Return-on-Sales & -.0409 & .0281 & 0.14 & -.0227 & .0073 & 0.002 \\
\hline Q & -.0028 & .00099 & 0.005 & -.00042 & .00030 & 0.16 \\
\hline Sectoral Q & .0009 & .0016 & 0.58 & .0003 & .0005 & 0.54 \\
\hline Leverage & .0057 & .0037 & 0.12 & .0010 & .0009 & 0.30 \\
\hline Sectoral Leverage & .00025 & .0146 & 0.98 & .00008 & .0044 & 0.98 \\
\hline Income Gearing & .000026 & .00013 & 0.84 & .00035 & .00032 & 0.28 \\
\hline Sectoral Income Gearing & -.00012 & .00018 & 0.49 & .00021 & .0012 & 0.86 \\
\hline Takeover Rumours & .0384 & .0117 & 0.001 & .0159 & .0071 & 0.03 \\
\hline Rumour-Size Interaction & -.0030 & .0015 & 0.05 & -.0022 & .0012 & 0.07 \\
\hline Age 1-5 Years Dummy & .0754 & .0100 & 0.000 & .0182 & .0050 & 0.000 \\
\hline Age 6-9 Years Dummy & .0267 & .0055 & 0.00 & .0070 & .0023 & 0.003 \\
\hline
\end{tabular}

Notes:

1. Time dummies are included.

2. Industry dummies are insignificant and thus excluded. 
3. Regressors scaled so that means lie on the unit interval. Marginal effects evaluated at means of variables. 
Table 5: Takeover likelihood model: Failed versus successful

Multinomial logit regression.

Sample period is 1989-96. Number of observations $=4100$.

Log Likelihood $=-652.77$. Likelihood Ratio Index $=0.1036$

Coefficients. $\chi^{2}(34)=150.82$; P-Value $=0.0000$

\begin{tabular}{|c|c|c|c|c|c|c|}
\hline & \multicolumn{3}{|c|}{ Acquired Companies } & \multicolumn{3}{|c|}{ Targets of Lapsed Bids } \\
\hline Variable & Coefficient & $\begin{array}{c}\text { Standard } \\
\text { error }\end{array}$ & P-Value & Coefficient & $\begin{array}{c}\text { Standard } \\
\text { error }\end{array}$ & P-Value \\
\hline Log Real Capital Stock & -.1334 & .0647 & 0.04 & .2934 & .1423 & 0.06 \\
\hline Return-on-Sales & -1.4426 & 1.2346 & 0.24 & -2.5333 & 2.9701 & 0.41 \\
\hline $\mathrm{Q}$ & -.1158 & .0465 & 0.01 & -.4761 & .2271 & 0.005 \\
\hline Sectoral Q & .0409 & .0728 & 0.57 & .2182 & .1645 & 0.22 \\
\hline Leverage & .2347 & .1676 & 0.15 & .6832 & .5128 & 0.16 \\
\hline Sectoral Leverage & .0720 & .6493 & 0.91 & -.7644 & 1.489 & 0.60 \\
\hline Income Gearing & .0020 & .0061 & 0.77 & .1684 & .1088 & 0.15 \\
\hline Sectoral Income Gearing & -.0100 & .0082 & 0.21 & .0137 & .1111 & 0.89 \\
\hline Takeover Rumours & 1.4478 & .4979 & 0.005 & 2.1225 & 1.1420 & 0.09 \\
\hline Rumour-Size Interaction & -.1017 & .0657 & 0.12 & -.2035 & .1396 & 0.16 \\
\hline Age 1-5 Years Dummy & 2.7517 & .3412 & 0.000 & 1.9916 & 1.1843 & 0.13 \\
\hline
\end{tabular}

Marginal effects. $\chi^{2}(34)=132.94 ;$ P-Value $=0.0000$.

\begin{tabular}{|l|r|r|r|r|r|r|}
\hline & \multicolumn{2}{|c|}{ Acquired Companies } & \multicolumn{3}{c|}{ Targets of Lapsed Bids } \\
\hline \multicolumn{1}{|c|}{$\begin{array}{c}\text { Marginal } \\
\text { effect }\end{array}$} & $\begin{array}{c}\text { Standard } \\
\text { error }\end{array}$ & P-Value & $\begin{array}{c}\text { Marginal } \\
\text { effect }\end{array}$ & $\begin{array}{c}\text { Standard } \\
\text { error }\end{array}$ & P-Value \\
\hline Log Real Capital Stock & -.0031 & .0014 & 0.04 & .00058 & .00031 & 0.06 \\
\hline Return-on-Sales & -.0333 & .0286 & 0.24 & -.0049 & .0060 & 0.41 \\
\hline Q & -.0026 & .0010 & 0.01 & -.00093 & .00033 & 0.005 \\
\hline Sectoral Q & .0009 & .0016 & 0.57 & .00042 & .00035 & 0.22 \\
\hline Leverage & .0054 & .0038 & 0.15 & .0013 & .00095 & 0.16 \\
\hline Sectoral Leverage & .0017 & .0150 & 0.91 & -.0015 & .0029 & 0.60 \\
\hline Income Gearing & .00004 & .0001 & 0.77 & .00033 & .00023 & 0.15 \\
\hline Sectoral Income Gearing & -.0002 & .0001 & 0.21 & .00002 & .0002 & 0.89 \\
\hline Takeover Rumours & .0334 & .0117 & 0.005 & .0041 & .0024 & 0.09 \\
\hline Rumour-Size Interaction & -.0023 & .0015 & 0.12 & -.00039 & .00028 & 0.16 \\
\hline Age 1-5 Years Dummy & .0637 & .0093 & 0.000 & .0037 & .0025 & 0.13 \\
\hline
\end{tabular}

Notes:

1. Time dummies are included.

2. Industry dummies are insignificant and thus excluded.

3. Regressors scaled so that means lie on the unit interval. Marginal effects evaluated at means of variables.

4. Model is poorly determined in the presence of Age 6-9 Years Dummy, so this variable is excluded. 


\section{Table 6: Takeover likelihood model: Friendly versus Hostile}

Multinomial logit regression.

Sample period is 1989-96. Number of observations $=4100$.

Log Likelihood $=-577.6$. Likelihood Ratio Index $=0.1283$

Coefficients. $\chi^{2}(34)=170.09 ;$ P-Value $=0.0000$.

\begin{tabular}{|c|c|c|c|c|c|c|}
\hline & \multicolumn{3}{|c|}{ Friendly Acquirees } & \multicolumn{3}{|c|}{ Hostile Acquirees } \\
\hline Variable & Coefficient & $\begin{array}{c}\text { Standard } \\
\text { error }\end{array}$ & P-Value & Coefficient & $\begin{array}{c}\text { Standard } \\
\text { error }\end{array}$ & P-Value \\
\hline Log Real Capital Stock & -.1509 & .0759 & 0.04 & .0907 & .1285 & 0.46 \\
\hline Return-on-Sales & -1.3288 & 1.4109 & 0.34 & -1.2090 & 2.6559 & 0.66 \\
\hline Q & -.1096 & .0473 & 0.01 & -.2882 & .1557 & 0.03 \\
\hline Sectoral Q & .0624 & .0793 & 0.42 & -.0871 & .1654 & 0.59 \\
\hline Leverage & .3016 & .1597 & 0.05 & -.7766 & .9460 & 0.40 \\
\hline Sectoral Leverage & -.2647 & .7494 & 0.72 & 1.0993 & 1.2956 & 0.40 \\
\hline Income Gearing & .0062 & .0514 & 0.90 & .0024 & .0056 & 0.67 \\
\hline Sectoral Income Gearing & .0250 & .0541 & 0.64 & -.0176 & .0087 & 0.05 \\
\hline Takeover Rumours & 1.7670 & .6930 & 0.01 & 2.1491 & .8090 & 0.02 \\
\hline Rumour-Size Interaction & -.1718 & .0972 & 0.08 & -.1560 & .0964 & 0.12 \\
\hline Age 1-5 Years Dummy & 3.1745 & .3634 & 0.00 & 2.1886 & .8567 & 0.03 \\
\hline Age 6-9 Years Dummy & 1.4350 & .2586 & 0.00 & -.8168 & 1.0486 & 0.41 \\
\hline
\end{tabular}

Marginal effects. $\chi^{2}(34)=123.4$; P-Value $=0.0000$.

\begin{tabular}{|l|r|r|r|r|r|r|}
\hline & \multicolumn{2}{|c|}{ Friendly Acquirees } & \multicolumn{3}{c|}{ Hostile Acquirees } \\
\hline \multicolumn{1}{|c|}{$\begin{array}{c}\text { Marginal } \\
\text { effect }\end{array}$} & $\begin{array}{c}\text { Standard } \\
\text { error }\end{array}$ & P-Value & $\begin{array}{c}\text { Marginal } \\
\text { effect }\end{array}$ & $\begin{array}{c}\text { Standard } \\
\text { error }\end{array}$ & P-Value \\
\hline Log Real Capital Stock & -.0025 & .0012 & 0.04 & .0003 & .0004 & 0.46 \\
\hline Return-on-Sales & -.0221 & .0236 & 0.34 & -.0038 & .0087 & 0.66 \\
\hline Q & -.0018 & .00076 & 0.01 & -.00092 & .00043 & 0.03 \\
\hline Sectoral Q & .0010 & .0013 & 0.42 & -.00028 & .0005 & 0.59 \\
\hline Leverage & .0050 & .0026 & 0.05 & -.0025 & .0030 & 0.40 \\
\hline Sectoral Leverage & -.0044 & .0125 & 0.72 & .0035 & .0042 & 0.40 \\
\hline Income Gearing & .0001 & .0008 & 0.90 & .000007 & .00001 & 0.67 \\
\hline Sectoral Income Gearing & .0004 & .0008 & 0.64 & -.000058 & .000029 & 0.05 \\
\hline Takeover Rumours & .0294 & .0117 & 0.01 & .0068 & .0029 & 0.02 \\
\hline Rumour-Size Interaction & -.0028 & .0016 & 0.08 & -.00049 & .00032 & 0.12 \\
\hline Age 1-5 Years Dummy & .0529 & .0078 & 0.00 & .0068 & .0032 & 0.03 \\
\hline Age 6-9 Years Dummy & .0240 & .0045 & 0.00 & -.0027 & .0033 & 0.41 \\
\hline
\end{tabular}

Notes:

1. Time dummies are included.

2. Industry dummies are insignificant and thus excluded. 
3. Regressors scaled so that means lie on the unit interval. Marginal effects evaluated at means of variables. 
Figure 1: Distribution of rumour count

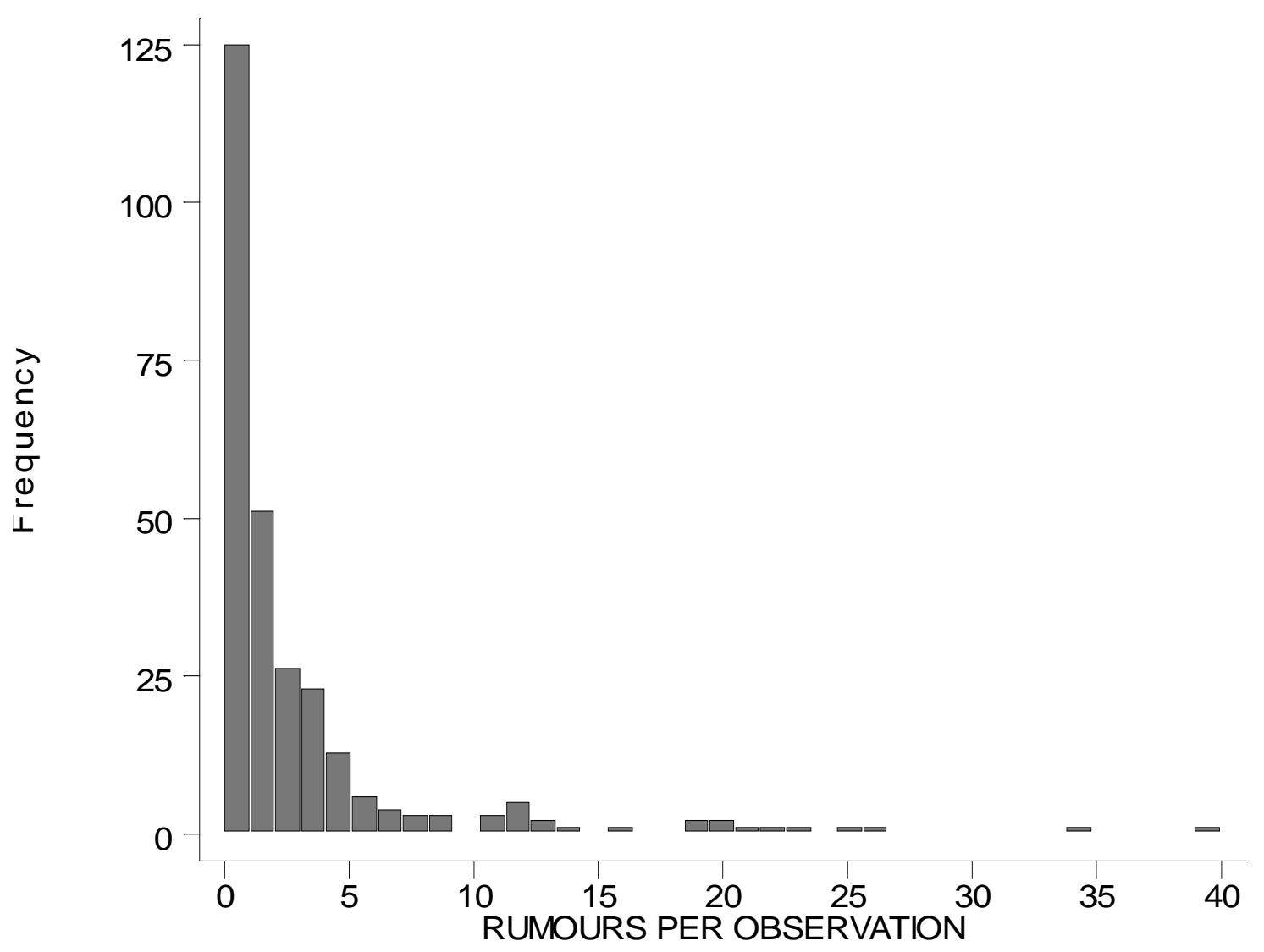

Notes:

1. Histogram displays number of rumours per observation (that is, per company per year).

2. The zero-rumour category has a frequency of 3823 , and is omitted from the histogram above. 


\section{References}

Ambrose, B W \& W L Megginson. 1992. The Role of Asset Structure, Ownership Structure, and Takeover Defenses in Determining Acquisition Likelihood. Journal of Financial and Quantitative Analysis 27(4): 575-589.

Blundell, R, Bond, S \& C Meghir. 1992. Econometric Models of Company Investment. In Matyas, L \& P Sevestre, eds. The Econometrics of Panel Data: Handbook of Theory and Applications. Dordrecht: Kluwer Academic. Pages 388-413.

Bulow, J \& P Klemperer. 1996. Auctions versus Negotiations. American Economic Review 86(1): 180-194.

Cameron, A C \& F A G Windmeijer. 1997. An R-squared Measure of Goodness of Fit for Some Common Nonlinear Regression Models. Journal of Econometrics 77(1): 329-342.

Comment, R \& G W Schwert. 1995. Poison or Placebo? Evidence on the Deterrent and Wealth Effects of Modern Antitakeover Measures. Journal of Financial Economics. 39(1): 3-44.

Comment, R \& G W Schwert. 1997. Hostility in Takeovers: In the Eyes of the Beholder? Mimeo, University of Rochester.

De, S \& P J Knez. 1993. Managerial Reaction to Takeover Bids: A Theory of Strategic Resistance. Journal of Economics and Management Strategy 2(4): 567-592.

Dickerson, A P, Gibson, H D \& E Tsakalotos. 1998. Takeover Risk and the Market for Corporate Control: The Experience of British Firms in the 1970s and 1980s. University of Kent at Canterbury, Department of Economics Discussion Paper 98/3.

Geroski, P A. 1995. What Do We Know About Entry? International Journal of Industrial Organization 13(4): 421-440.

Greene, W H. 1997. Econometric Analysis. London: Prentice-Hall. Third Edition.

Grossman, S J \& O D Hart. 1980. Takeover Bids, the Free-Rider Problem and the Theory of the Corporation. Bell Journal of Economics 11: 42-64.

Grossman, S J \& O D Hart. 1986. The Costs and Benefits of Ownership: A Theory of Vertical and Lateral Integration. Journal of Political Economy 94(4): 691-719.

Hart, O. 1995. Firms, Contracts, and Financial Structure. OUP.

Hart, O \& J Moore. 1990. Property Rights and the Nature of the Firm. Journal of Political Economy 98(6): 1119-1158. 
Hart, O \& J Moore. 1994. A Theory of Debt Based on the Inalienability of Human Capital. Quarterly Journal of Economics 109(4): 841-79.

Hayashi, F. 1982. Tobin's Marginal q and Average q: A Neoclassical Interpretation. Econometrica 50: 213-224.

Jovanovic, B. 1982. Selection and the Evolution of Industry. Econometrica 50(3): 649-670.

Mikkelson, W H \& M M Partch. 1989. Managers' Voting Rights and Corporate Control. Journal of Financial Economics 25(2): 263-290.

Milgrom, P \& J Roberts. 1992. Economics, Organization and Management. Englewood Cliffs, NJ: Prentice Hall.

Morck, R, Shleifer, A \& R W Vishny. 1988. Characteristics of Targets of Hostile and Friendly Takeovers. In Auerbach, A J, ed. Corporate Takeovers: Causes and Consequences. University of Chicago Press. Pages 101-129.

Morck, R, Shleifer, A \& R W Vishny. 1989. Alternative Mechanisms for Corporate Control. American Economic Review 79(4): 842-852.

Nickell, S J. 1995. The Performance of Companies. Oxford: Blackwell.

Nuttall, R. 1999a. An Empirical Analysis of the Effects of the Threat of Takeover on UK Company Performance. Nuffield College, Oxford, Discussion Paper.

Nuttall, R. 1999b. Essays on Contracts and Takeovers. Unpublished doctoral thesis, Oxford Oxford.

Palepu, K G. 1986. Predicting Takeover Targets: A Methodological and Empirical Analysis. Journal of Accounting and Economics 8(1): 3-35.

Powell, R G. 1997. Modelling Takeover Likelihood. Journal of Business Finance \& Accounting 24(7/8): 1009-1031.

Schwert, G W. 1996. Markup Pricing in Mergers \& Acquisitions. Journal of Financial Economics 41: 153-192

Schmidt, K M. 1997. Managerial Incentives and Product Market Competition. Review of Economic Studies 64(2): 191-213.

Shivdasani, A. 1993. Board Composition, Ownership Structure, and Hostile Takeovers. Journal of Accounting and Economics 16: 167-198.

Shleifer, A \& L H Summers. 1988. Breach of Trust in Hostile Takeovers. In Auerbach, A J, ed. Corporate Takeovers: Causes and Consequences. University of Chicago Press. Pages 33-56. 
Shleifer, A \& R W Vishny. 1986. Large Shareholders and Corporate Control. Journal of Political Economy 94(3): 461-488.

Shleifer A \& R W Vishny. 1988. Value Maximization and the Acquisition Process. Journal of Economic Perspectives 2(1): 7-20.

Shleifer A \& R W Vishny. 1997. A Survey of Corporate Governance. Journal of Finance 52(2): 737-783.

Stiglitz, J E \& A Weiss. Credit Rationing in Markets with Imperfect Information. American Economic Review 71(3): 393-410.

Zingales, L. 1995. Insider Ownership and the Decision to Go Public. Review of Economic Studies. 62: 425-448.

Zwiebel, J. 1995. Block Investment and Partial Benefits of Corporate Control. Review of Economic Studies 62(2): 161-185.

Zwiebel, J. 1996. Dynamic Capital Structure under Managerial Entrenchment. American Economic Review 86(5): 1197-1215. 